\title{
A Dynamic Just-in-Time Component Delivery Framework for Off-Site Construction
}

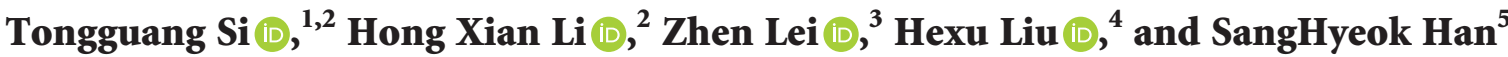 \\ ${ }^{1}$ School of Management Engineering, Shandong Jianzhu University, 1000 Fengming Road, 250101 Jinan, China \\ ${ }^{2}$ School of Architecture \& Built Environment, Deakin University, Geelong, VIC 3220, Australia \\ ${ }^{3}$ Department of Civil Engineering, University of New Brunswick, Fredericton, NB E3B 5A3, Canada \\ ${ }^{4}$ Department of Civil and Construction Engineering, Western Michigan University, Kalamazoo 49008-5316, USA \\ ${ }^{5}$ Department of Building, Civil, and Environmental Engineering, Concordia University, Montreal H3G 1M8, Canada \\ Correspondence should be addressed to Tongguang Si; sito@deakin.edu.au and Hong Xian Li; hong.li@deakin.edu.au
}

Received 16 March 2021; Accepted 2 June 2021; Published 16 June 2021

Academic Editor: Suvash Paul

Copyright (C) 2021 Tongguang Si et al. This is an open access article distributed under the Creative Commons Attribution License, which permits unrestricted use, distribution, and reproduction in any medium, provided the original work is properly cited.

\begin{abstract}
Off-site construction entails various advantages compared with the traditional construction method; however, the fragmentation of the prefabrication and assembly results in a complex supply chain. Both general contractors and factories often encounter production deviation, making the original component delivery plan nonoptimal. Traditionally, both parties tend to rely on internal resources or third-party resources to manage schedule changes, paying little attention to the optimisation of the component delivery process. The static compensation mechanisms reported in existing literature require factories to manage demand fluctuations but fail to encourage general contractors to control schedule deviations. Therefore, a dynamic compensation mechanism is proposed to achieve just-in-time component delivery, with which a factory shares possible changes for each component's delivery date to its clients on an inverse Kanban system. First, unfavourable changes for the factory schedule are allocated with surcharges, and the general contractor should compensate the factory if it accepts the date changes; secondly, schedule changes that are beneficial for the factory are assigned as incentives, and the general contractor receives the factory's incentive upon agreeing to the changes. Based on these two scenarios, genetic algorithm-based optimisation models are developed to achieve optimal delivery planning solutions. General contractors can obtain an optimal component delivery date to reduce the additional cost when they have changed the assembly schedule. General contractors can also optimise their component delivery schedule to trade their duration flexibility for incentives offered by factories. The models can help both parties to reduce component delivery waste when either side has the motivation to change the original component delivery schedules.
\end{abstract}

\section{Introduction}

Off-site construction (OSC) offers higher productivity, better quality, higher production controllability, shortened project duration, less project-lifecycle cost [1], and fewer environmental impacts compared with in-situ construction [2-4]. According to a general contractor's orders, a building's components are first manufactured in a factory workshop, then transported, and finally assembled at a construction site [5]. The fragmentation of prefabrication and assembly, however, makes the supply chain difficult to manage. The OSC parties have different goals and value systems [6], often resulting in unsatisfied management of schedule and resources, low control of workflows, and inadequate information sharing [7]. The general contractors and the subcontractors usually have a mistrustful and conflicting relationship [8]. Lack of collaboration and communication remains one of the main reasons for construction project failure [9]. Poor collaboration between stakeholders is still among the primary risks affecting the performance of OSC [10-12]. For example, OSC in Hong Kong suffers from low efficiency of resource planning, working process control, and information-sharing between participants. The stakeholders work independently without timely or efficient information-sharing about the actual progress or changes [7]. 
The performance of an OSC can be maximised if a project progresses as scheduled. Nevertheless, changes are inevitable in construction projects $[13,14]$. Uncertainties can result from inclement weather, equipment failure, shortage or low productivity of labour, or late delivery by suppliers [13, 15]. Early or late delivery of manufactured components would be a loss to the general contractors [16]. A factory's ability to deliver also suffers from variations in resource availability [17], equipment failure [18, 19], change of on-site requirements [20], the accuracy of manufacturing [21], lost productivity, and variations in setup times [19].

Eliminating waste is the initial motivation of the Toyota production system (TPS) or lean production. Waste in manufacturing production has been principally identified as inventory, waiting, transportation, overprocessing, overproduction (more or earlier than needed), movement, and defective products [22]. As a deliberatively introduced waste [23], inventory is designed to maintain smooth production. Ohno [22] insisted that excess inventory was the most significant waste because it causes secondary waste, such as transportation, double handling, and possible damage. Overburdening people or equipment is another type of waste, often resulting in safety problems, equipment breakdowns, and quality problems [24].

Just-in-time, which means "in a flow process, the right parts needed in assembly reach the assembly line at the time they are needed and only in the amount needed," aims to reduce or eliminate inventory and related waste [22]. Justin-time is commonly applied as a production system, a management philosophy [25, 26], a TPS practice [27], a methodology [28], a principle [29-31], or an approach [32]. Pull system is one of the TPS tools to achieve just-in-time for thousands of parts-the end-users trigger upstream production to meet their requirements at the minimum quantity and right time [33]. As the TPS operating method and the tool realising just-in-time, Kanban holds the information for the products that are actually required by the downstream in paper form to prevent overproduction and extra inventory [22].

In the existing literature on construction management, waste reduction does not capture extensive attention [34]. Inefficient management and organisation have been identified as the key problems of the construction industry [35], and just-in-time is the solution to the component delivery problem [36, 37]. Pull-driven production is a method to achieve just-in-time and suits the projects that face high levels of uncertainty [38]. By using Kanban, the downstream pull production from the upstream meets the actual requirements [33].

Like lean production, lean construction strives for optimal plans to address deviation and waste with contextual captured knowledge and continual corrections [39] to create value for customers from project conception to delivery [40, 41]. Koskela [35] defined all waste as unnecessary or nonvalue adding in production and stated that nonvalueadded activities were by-products of the division and specialisation of the tasks. According to lean construction, Hosseini et al. [42] defined process waste as nonphysical waste during the construction processes, including defects, rework, overproduction, unnecessary inventory handling time, transportation, and waiting.

If on-site assembly progresses as scheduled, all components will be delivered just in time for assembly activities, causing no inventory waste. However, delivering components as scheduled would cause additional inventory for general contractors when progress deviates from (usually later than) the original plan. Luo et al. [7] reported that in the OSC's complex supply chain, poor communication and insufficient coordination could cause waste such as additional inventory, transportation, double handling, and possible damage when variations occur. Vrijhoef and Koskela [43] pointed out that the time waste between activities significantly impacted the total time for the entire process. Large inventory and lack of sufficient care are the leading issues of on-site stock management [44]. Wu and Feng [45] identified the inventory problem as the most critical nonvalue-adding activity. Viana et al. [46] reported that $60 \%$ of the components in on-site warehouses would be assembled more than ten days after they are delivered. Due to the limited capacity of on-site warehouses, general contractors have to lease nearby land [47] or use the logistics providers' warehouse to store excessive components $[48,49]$. A factory's ability to deliver can be affected by multiple kinds of uncertainties, such as lost productivity [50], equipment failure, variations in setup times [19], unexpected work defect [51], and material-related conditions [15]. If a factory experiences unexpected production interruption, overtime is required to meet the due date. The worst situation is when the assembly of the components produced in extra time is delayed, leading to waste on both sides. A general contractor usually has float time as a production resource $[52,53]$ for timely project completion [54]. Even if the general contractor does not delay the assembly schedule as a response to uncertainties, float time can allow for an adjustment to the assembly schedule, thereby enabling the factory to change the component delivery date. However, little literature focuses on accepting suppliers' delivery delays.

As one type of process waste identified with lean philosophy, component delivery waste in OSC is defined as time, inventory, and cost waste in component delivery processes when factories and general contractors individually deal with schedule deviations. There are two types of possible waste when the components are delivered on nonoptimal dates: (1) general contractor's additional inventory cost, transportation, and double handling when the assembly is delayed and (2) factory's possible overtime work to meet the due date for the components, the assembly of which is to be delayed.

The increased cost caused by unsuccessful coordination between factory and general contractor often decreases benefits from OSC $[43,47]$. It is thus necessary to develop and use positive relationships between general contractors and factories [1]. Proper incentive systems are required to balance the stakeholders' incongruent goals and value systems [6]. More efficient communication between parties is required to capture contextual knowledge to improve coordination [55]. 
Given these abovementioned challenges, the present research aims to reduce component delivery waste by facilitating general contractors and factories to share their production resources with a dynamic compensation mechanism and optimisation models. The remainder of the paper is structured as follows: (1) the literature review section includes a comprehensive review of the literature concerning engineer-to-order, compensation mechanism, optimisation for the improvement of OSC production, and the research gaps identified by summarising the relevant studies; (2) the methodology section introduces a dynamic compensation mechanism and mathematical models for two delivery scenarios; (3) the results and discussion section contains the demonstration and discussion of two example models; and (4) the conclusion section includes the conclusions, limitations, and proposed future work.

\section{Literature Review}

2.1. The Engineer-to-Order (ETO) Nature of Component Delivery. Engineer-to-order (ETO) production is driven by customer orders rather than demand prediction [56]. Such highly customised products make the ETO supply chain less flexible on demand variation and vulnerable to uncertainty. Uncertainties, however, could come from suppliers, manufacturers, and customers [57]. Gosling et al. [58] reported four uncertainty factors in ETO production, namely (1) the unavailability of timely and accurate information from clients, (2) the inaccuracy of the project plan, (3) early or late delivery, and (4) changes in specification. Ko [19] claimed that demand variation imposes the most significant challenges as finished components would be changed in terms of the size, quantity, and delivery date. Customer order changes and information-sharing are identified as two factors influencing coordination between ETO stakeholders [59]. As such, ETO suppliers should offer product flexibility, workforce flexibility [60], process flexibility, volume flexibility, and delivery flexibility [61] to cope with uncertainties [62]. Gosling and Naim [56] argued that information management was the effective approach for coping with uncertainties for ETO suppliers. OSC production can be defined as ETO, usually involving design, prefabrication, delivery, and assembly processes [63]. Since the customised components cannot be repurposed as raw materials, if the construction schedule deviates, it causes waste in terms of space, time, and finance in order to deal with such cumbersome objects.

2.2. Just-in-Time Delivery in Construction. Just-in-time aims to achieve zero-inventory production, i.e., reducing stocks both in raw materials delivery and work-in-progress products [64]. The just-in-time philosophy can improve the delivery of manufactured components from factories to construction sites, thereby alleviating the space issue and traffic congestion [47]. Im et al. [65] developed a just-in-time delivery system between a rebar assembly and rebar supplier site based on Monte Carlo simulation and optimisation techniques, intending to reduce inventory levels. In an effort to adopt just-in-time in the ready-mix concrete (RMC) industry in Singapore and Chongqing, China, Low and $\mathrm{Wu}$ [66] reported that all the surveyed suppliers managed RMC production and delivered the products to sites with the demand-pull system of the just-in-time approach. Chen et al. [67] developed a just-in-time ready-mix concrete coordination approach to revise original orders to accommodate the demand variations.

Just-in-time delivery has proven to be an effective solution to inventory waste at construction sites [47]. Rebar and RMC are not ETO products, and they can be easily redirected to other clients when the original order is changed or cancelled. M. Goh and Y. M. Goh [68] pointed out that a complete just-in-time system was not achievable due to the uncertainty in the construction industry. Stakeholders in the OSC supply chain have different interests and may not naturally achieve just-in-time delivery. Financial incentives are necessary to motivate the factories to commit to just-intime coordination $[38,47]$.

2.3. Compensation Systems to Encourage Just-in-Time Delivery. Because factories and general contractors are independent for-profit organizations, just-in-time delivery cannot be achieved naturally. A case study shows that if the incentivization of all parties is not properly arranged, the project-based view cannot be compatible with the firmbased view in cooperation between general contractors and their suppliers [69]. Pheng and Chuan [47] reported that complete just-in-time delivery in construction is not practical because of the interdependence of participants and the varying conditions. Furthermore, incentives or compensation have been proposed in extant literature.

National and AIA California Council [70] defines integrated project delivery (IPD) as "a project delivery approach that integrates people, systems, business structures and practices into a process that collaboratively harnesses the talents and insights of all stakeholders to optimise project results, increase value to the owner, reduce waste, and maximise efficiency through all phases of design, fabrication, and construction." With IPD, shared goals are expressly stated in the early stage of the project, and success or failure leads to different financial consequences for parties [70]. With a multiparty contract, construction parties collaborate to achieve the shared goals combined with incentives to maximise both the individual and project interests [71]. "Incentive pool," as a reward mechanism, is implemented by reserving a unique portion of the related participant's expenses into a pool that can be distributed to the participants based on the entire project achievements [72]. The risksharing and reward-sharing mechanism boosts mutual respect and trust among stakeholders and encourages open communication, collaborative decision-making and control, and transparent financials [73]. The approach has been enhanced with BIM (building information model) and lean practices and improved project performance, especially cost performance and schedule performance [74].

Although BIM-enabled IPD platform has significantly improved cost estimation and risk-sharing fairness [75], the 
IPD approach is essentially a strategic win-win technique $[76,77]$ as a contracting method to encourage parties to collaborate as a team. Component delivery, however, is an operational-level activity. The cost of a component delivery date change is quantifiable, and solutions would not naturally produce tactical win-win outcomes, even if it is not always zero-sum. An explicit, quantitative compensation would more efficiently encourage parties to coordinate to achieve just-in-time directly with balanced interest allocation.

Ju et al. [72] stated that redistributing the responsibilities between the downstream and the upstream could encourage the party that can reduce conflicts at a lower cost to address uncertainties. Reimbursement is proposed to motivate the factories to commit to just-in-time delivery, but no further information is given [38, 47]. Pheng and Chuan [78] reported that more than one-third of general contractors agreed to pay an additional $0.25 \%-5 \%$ of the contract sum for flexible and reliable delivery as value-added service to reduce extra double handling, use of cranage service, and risk of damage. Khalfan et al. [79] report a supplier-Kanban to achieve just-in-time production in an innovative material procurement for a public organisation in the United Kingdom. The client plays the role of "supply chain integrator," focusing on value stream rather than the traditional profit-based view. The quality-price mechanism, instead of the lowest tender, is adopted as the standard for selecting suppliers. The participants work as an integrated organisation, and demands are sent to the suppliers with supplierKanban on the information system. The suppliers "must" deliver the desired items to the construction site in time with a fleet of vehicles for routine material collection and delivery.

Waste commonly stems from previous stages in the supply chain or prior production tasks $[35,43]$. Pheng and Chuan [47] also revealed that general contractors should take more responsibility to implement just-in-time production in OSC. The cost of a delivery date change may vary because of the real-time resource constraints of factories. For example, the cost of later delivery of a component is higher when the factories have less available inventory. With the aforementioned inter-organizational just-in-time delivery systems, they pay fixed compensation, regardless of whether or how many general contractors change the component delivery date. The suppliers assume all the responsibility of handling demand fluctuation. Such compensation systems cannot correctly reflect the dynamic cost of the date change, and general contractors do not have the motivation to control their schedule fluctuation.

\subsection{Optimisation for Just-in-Time. Optimisation algorithms} have been used in off-site production to achieve just-in-time production and delivery. With just-in-time approaches, researchers developed a linear programming-based product mix optimisation model and a sequence optimisation model to improve the performance of the internal production planning in manufactured housing [80]. Some research focuses on the supply chain to obtain multi-objective and holistic optimisation by reducing the changeover time of jobs and impacts of uncertainties, coordinating manufacturing, transportation, and assembly as integrated processes [13, 81-83]. Information technology plays a significant role in improving the performance of the prefabrication and assembly to realise timely component delivery and just-in-time production of entire projects. Nevertheless, optimising within a single phase without shared data from other stakeholders makes it difficult to achieve global optimisation from the perspective of the entire project. On the other hand, OSC participants are usually financially independent, and it is not practical to directly optimise interorganizational activities.

Due to the highly uncertain environment, the preponderance of ETOs, production concurrency, and prefabrication and assembly fragmentation, there are nonvalueadded activities and resultant waste in component delivery when variations occur. Although just-in-time production has been proven successful within manufacturing organizations, component factories and general contractors could not naturally achieve just-in-time delivery as financially independent participants. Static compensation solutions in the extant literature could not correctly reflect the actual cost caused by the change of delivery dates, thereby failing to encourage general contractors to manage variations to reduce waste. Information technology plays a significant role in realising timely delivery and just-in-time production of projects; however, optimisation in one organisation without shared data tends to carry out a local optimum and centralised-optimisation is not in conformity with the business model.

\section{Research Objective and Methodology}

With the aim of achieving just-in-time component delivery, a dynamic compensation mechanism and two mathematical models are proposed to reduce waste related to component delivery.

To achieve the objective, the research methodology is proposed as presented in Figure 1, in which the input of parameters include: (1) the original component delivery schedule; (2) the component delivery date change and associated surcharges/incentives offered by the factory; (3) the on-site inventory cost and double handling cost, which are only known to the general contractor; and (4) the third-party inventory cost and double handling cost, which are known to the general contractor and the factory. The main process follows five steps: (1) study the supply chain; (2) create a dynamic compensation mechanism; (3) formalise mathematical models for two scenarios; (4) apply the genetic algorithm (GA) to solve the model; and (5) discuss the optimisation results.

The proposed methodology is subject to the following criteria: precedence relationship of activities and the maximum allowance for a date change of specific tasks which the general contractor specifies. The output involves the revised component delivery schedule, the total cost of the revised component delivery schedule when the general contractor changes the delivery date to deal with its assembly schedule deviations, and the total revenue of the revised component 


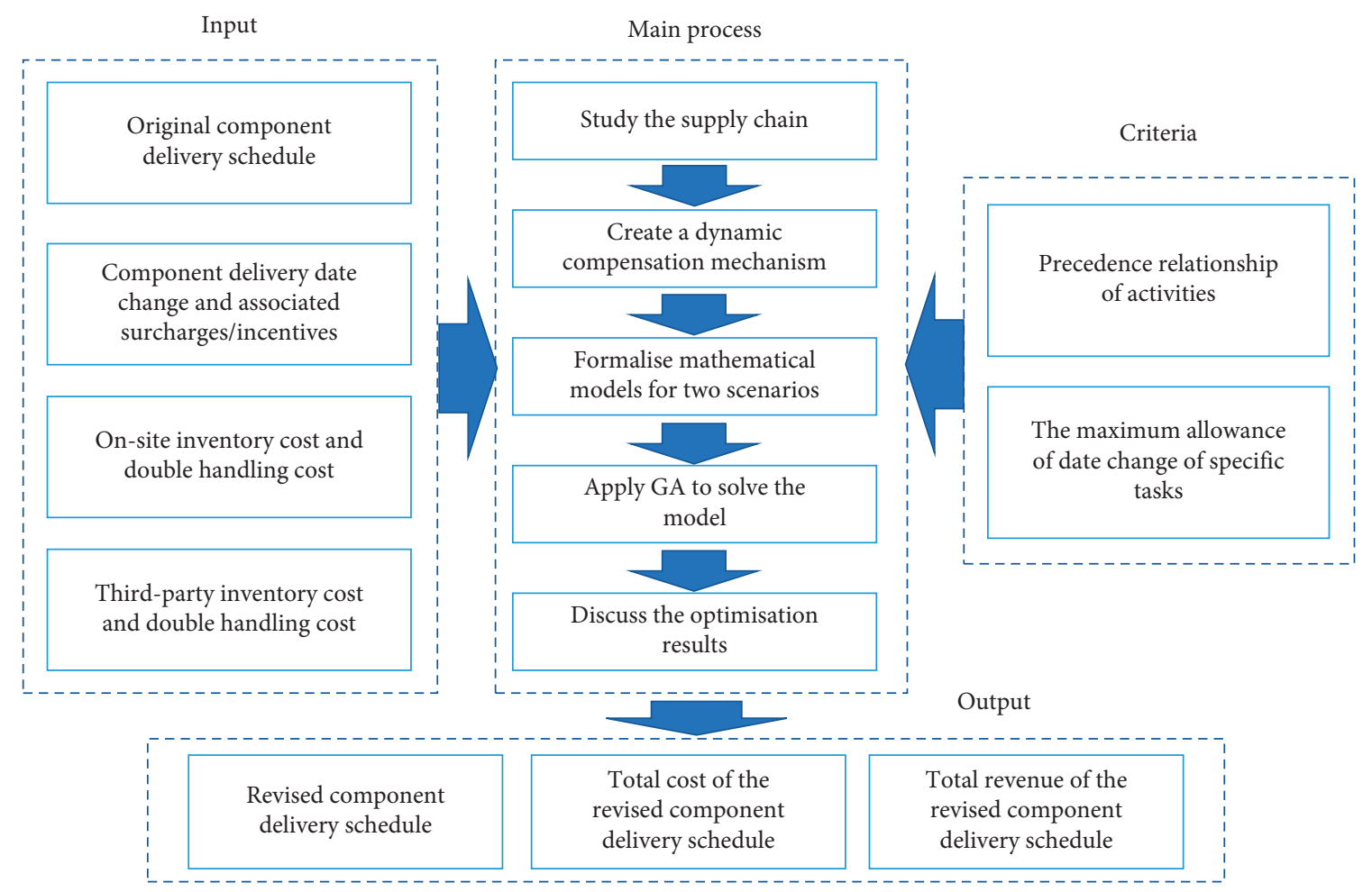

Figure 1: Methodological framework.

delivery schedule when the general contractor tries to trade its schedule flexibility for incentives offered by the factory.

This research is also based on the following assumptions:

(1) The many-to-many relationship between general contractors and factories can be simplified to a oneto-one relationship between a general contractor and a factory.

(2) The general contractor can predict its assembly progress seven days in advance. The factory can quantify the cost of a component delivery date change in real-time and share cost data with its clients. Both sides agree to change the component delivery date when certain conditions are satisfied.

(3) The capacity of third-party inventory is unlimited.

(4) The general contractor does not change the ordered quantities during coordination processes.

3.1. Dynamic Compensation Mechanism. One focus of lean production is to identify problems or waste in practice [24] and seek promotion with contextually captured knowledge [39]. It is essential to encourage participants to expose dynamic information to their partners in the supply chain. Chen et al. [84] stated that the incentive system and information-sharing were important enablers for the coordination of the construction supply chain. Simatupang and Sridharan [85] reported that explicit incentive alignment and fair compensation could motivate participants' desired behaviour in the supply chain with reciprocal interaction.
Production deviations could make either side's scheduled delivery nonoptimal. General contractors may have the motivation to change the delivery date to match their revised assembly schedule, and factories would seek to change the delivery date when they will have completed the production of components earlier or later than the due date. In the manufacturing industry, the upstream workstations produce according to Kanban, on which the demand information such as due data and amount is shown. The Kanban can reduce or eliminate overproduction (more or earlier than actually needed) waste to achieve just-in-time production. Component delivery waste in off-site construction supply chain results from the mismatch between the scheduled delivery date and the actual optimal delivery date, and can be identified as overproduction, which causes additional inventory waste and other resultant waste.

Based on the lean philosophy, a dynamic compensation mechanism is proposed to achieve the research aim. In addition to providing components, a factory offers the flexibility of delivery date. The factory dynamically assigns a positive number as a surcharge for compensation to the date change which increases its cost (e.g., additional inventory). In contrast, the factory allocates a negative number as an incentive to the favourable change (e.g., mitigation of resource contention) to encourage general contractors to make the change.

Table 1 shows the surcharges or incentives for the components' delivery date change, which are released and updated by the factory. In the table, a row represents the component's surcharges or incentives induced by the changed delivery date by a different number of days. For 
TABLE 1: Surcharges/incentives for delivery date delay released by the factory*

\begin{tabular}{lccccccc}
\hline Components & $1 \mathrm{~d}(\$)$ & $2 \mathrm{~d}(\$)$ & $3 \mathrm{~d}(\$)$ & $4 \mathrm{~d}(\$)$ & $5 \mathrm{~d}(\$)$ & $6 \mathrm{~d}(\$)$ & $7 \mathrm{~d}(\$)$ \\
\hline $\mathrm{C}_{1}$ & $s_{1}^{1}$ & $s_{1}^{2}$ & $s_{1}^{3}$ & $s_{1}^{4}$ & $s_{1}^{5}$ & $s_{1}^{6}$ \\
$\ldots$ & $\cdots$ & $\ldots$ & $\ldots$ & $\cdots$ & $\cdots$ & $\ldots$ & $\ldots$ \\
$\mathrm{C}_{n}$ & $s_{n}^{1}$ & $s_{n}^{2}$ & $s_{n}^{3}$ & $s_{n}^{4}$ & $s_{n}^{5}$ & $s_{n}^{6}$ \\
\hline
\end{tabular}

*Only delay-related data are shown; however, earlier delivery is also covered in the methodology.

example, $s_{2}^{4}$ represents the surcharge (a positive number) or incentive (a negative number) for component $C_{2}$ 's delivery occurring 4 days later than the date stipulated in the original order. To be clear, $C_{i}$ does not necessarily refer to a single component; it represents a part of an order and may contain tens of components.

The table serves as an inverse Kanban, with which the general contractors (the downstream parties) can retrieve possible component delivery change data offered by the factories. Rather than always accepting component delivery as scheduled, the general contractor could make decisions in two scenarios based on the surcharge/incentive data on the inverse Kanban:

Scenario 1: revises component delivery plan to minimise inventory and related cost when assembly schedule has been changed.

Scenario 2: changes assembly schedule to receive the maximum incentives from the factory.

In Scenario 1, the general contractor can manage schedule variations at a minimum cost to achieve or approximate just-in-time delivery to match the actual progress, and the factory can receive the compensation they claim. In Scenario 2, the general contractor could trade their schedule flexibility for incentives offered by the factory. If the general contractor achieves any better solution than accepting delivery as scheduled, both the general contractor and the factory change the delivery date. If there is no new agreement, the delivery is carried out on the date stipulated in the contracts.

As illustrated in Figure 2, the proposed compensation mechanism is embodied with a dynamic just-in-time component delivery framework. An information system holds shared information to facilitate coordination between the general contractor and the factory. The factory releases and updates the surcharges or incentives for the components' delivery date change to the information platform. The general contractor retrieves information from the information platform and revises its delivery schedule with optimisation, and then accordingly changes the delivery date and pays surcharges or receives incentives. The factory then changes the delivery date and receives surcharges or pays incentives. The factory releases the possible date change and associated financial data to the information platform according to its actual production resources (details are not included in the research); then, the general contractor makes a decision based on the shared data to revise their delivery schedule. The final step is that the factory updates the delivery date according to the general contractor's decision.

3.2. The Model for Scenario 1. When the assembly schedule is changed, delivering the related components as scheduled causes additional inventory cost. The third-party inventory cost is involved if on-site warehouse space is insufficient. Under such a circumstance, delaying the delivery of the affected components is an option. The general contractor retrieves the surcharge/incentive data and then carries out solutions to change the delivery date to minimise the total cost.

The model's inputs include (1) surcharges or incentives from the factory, as shown in Table 1, (2) the delay for assembly schedule, (3) the component's on-site inventory cost and the resultant double handling cost, and (4) the component's third-party inventory cost and related double handling cost. The model's output is the delivery delay for the components.

The model's objective is to minimise the general contractor's total cost, which incorporates the sum of the surcharges/incentives, the on-site inventory cost or the price of the third-party inventory, and related double handling cost, as formulated in equation (1). The constraint, expressed as equation (6), states that the delivery date must not be later than the assembly date.

$$
\text { Obj: Min } \begin{aligned}
T C & =C^{P}+C^{I}, \\
C^{P} & =\sum_{i} C_{i}^{P}, \quad i=1,2, \ldots, n, \\
C^{I} & =\sum_{i} V \cdot C^{U I} \cdot\left(d_{i}^{\text {assembly }}-d_{i}^{\text {delivery }}\right)_{i}+\sum_{i} V_{i} \cdot C^{D H}, \quad i=1,2, \ldots, n, \\
C^{U I} & = \begin{cases}\$ m / \text { day } / \mathrm{m}^{3}, & \text { stock level } \leq L, \\
\$ n / \text { day } / \mathrm{m}^{3}, & \text { stock level }>L,\end{cases}
\end{aligned}
$$




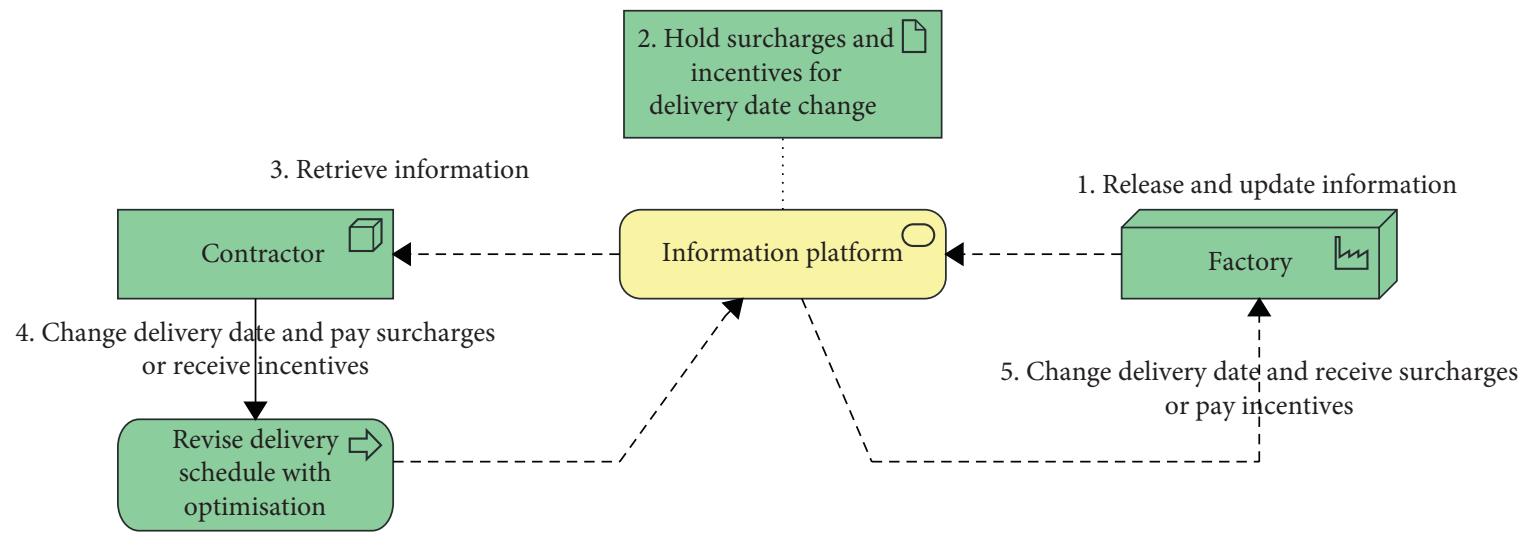

Figure 2: A dynamic just-in-time component delivery framework.

$$
\begin{gathered}
C^{D H}= \begin{cases}\$ p / \text { day } / \mathrm{m}^{3}, & \text { stock level } \leq L, \\
\$ q / \text { day } / \mathrm{m}^{3}, & \text { stock level }>L,\end{cases} \\
\text { subject to, } d_{i}^{\text {assembly }}-d_{i}^{\text {delivery }} \geq 0, \quad i=1,2, \ldots, n,
\end{gathered}
$$

where $C^{P}(\$)$ represents the payments (surcharges or incentives) to the factory from the general contractor for the component's delivery delay. $C^{I}(\$)$ indicates the opportunity cost of storing the component in the general contractor's warehouse or the third-party inventory and the resultant double handling cost. $V_{i}\left(\mathrm{~m}^{3}\right)$ represents the volume of the $i$ th component. $L\left(\mathrm{~m}^{3}\right)$ represents the capacity limit of the on-site inventory. $C^{U I}$ denotes the inventory cost. The $\$ m /$ day $/ \mathrm{m}^{3}$ represents the on-site inventory unit cost, and $\$ n /$ day $/ \mathrm{m}^{3}$ represents the third-party inventory unit cost. $C^{D H}$ denotes the unit cost of the double handling. The double handling cost of on-site inventory is $\$ p /$ time, and $\$ q /$ time refers to a different cost of the double handling to and from the third-party inventory. $d_{i}^{\text {assembly }}$ and $d_{i}^{\text {delivery }}$ represent the day when the $i$ th component is assembled and delivered, respectively. ( $\left.d_{i}^{\text {assembly }}-d_{i}^{\text {delivery }}\right)$ signifies the number of days that the $i$ th component is stored before assembly.

3.3. The Model for Scenario 2. A factory releases an incentive for a delayed delivery date of components if the delay is beneficial. A general contractor would actively trade its schedule's flexibility for incentives to achieve a win-win outcome. Apart from activities' precedence, fixed activities, for which the assembly date change is specified by the general contractor, are an additional constraint.

For clarity, a sample of incentive data and surcharges are presented in Table 2.

The model's input variables include (1) surcharges or incentives listed by the factory, as shown in Table 2, (2) assembly schedule of the general contractor, and (3) fixed activities for which the assembly date's maximum delay is specified. The model's outputs are a new schedule and the optimal revenue.

A general contractor regards incentives (negative numbers) as revenue and thus aims to maximise them. Due to the precedence constraints between activities, the general contractor must accept related surcharges when specific incentives are selected. No inventory cost is involved because the general contractor is trying to match the assembly date to the delivery date.

$$
\text { Obj : Max } \quad R=-\sum_{i=1}^{n} P_{i}, \quad i=1,2, \ldots, n,
$$

Subject to:

$$
\begin{aligned}
& s_{i}^{\prime}-s_{j}^{\prime} \geq d_{j}, j \in S_{i}, i=1,2, \ldots, n, \\
& s_{i}^{\prime}-s_{i} \leq b_{i}, i=1,2, \ldots, n, \\
& s_{i}^{\prime} \geq 0, \quad i=1,2, \ldots, n, \\
& R>0,
\end{aligned}
$$

where $i$ represents the index of the tasks (components). $C^{P}(\$)$ represents the payments (surcharges or incentives) to the factory from the general contractor for the delivery delay of components. $n$ represents the number of tasks (components). Constraint (8) states that the tasks cannot start before all predecessor tasks finish. $s_{i}^{\prime}$ and $s_{j}^{\prime}$ represent the start date of the $i$ th and $j$ th tasks in the new schedule, respectively. $d_{j}$ denotes the duration of the $j$ th task. $S_{i}$ signifies the set of the successor tasks of the $i$ th task. Constraint (9) limits the difference between the $i$ th task's start time in the new schedule and the original one. $s_{i}$ indicates the start date of the $i$ th task in the original schedule. $b_{i}$ represents the maximum allowance for a date change of the $i$ th task, which is specified as a fixed activity by the general contractor. Constraint (10) ensures that the start time of all tasks is equal to or greater than 0 in the new schedule. Constraint (11) ensures the revenue must be positive.

As an effective and commonly used optimisation algorithm, a GA is applied to resolve the above optimisation 
TABLE 2: Sample incentives and surcharges for delayed delivery.

\begin{tabular}{|c|c|c|c|c|c|c|c|}
\hline Components & $1 \mathrm{~d} \mathrm{( \$ )}$ & $2 \mathrm{~d}(\$)$ & $3 \mathrm{~d}(\$)$ & $4 \mathrm{~d} \mathrm{( \$ )}$ & $5 \mathrm{~d}(\$)$ & $6 \mathrm{~d} \mathrm{( \$ )}$ & $7 \mathrm{~d}(\$)$ \\
\hline $\mathrm{C} 01$ & 100 & 200 & 300 & 0 & 0 & 0 & -100 \\
\hline $\mathrm{C} 02$ & 100 & 0 & 0 & 200 & 400 & 600 & -800 \\
\hline $\mathrm{C} 03$ & 300 & -600 & 300 & 0 & 600 & 900 & 1,200 \\
\hline $\mathrm{C} 04$ & 400 & 800 & 0 & 400 & 800 & 1,200 & $-1,600$ \\
\hline $\mathrm{C} 05$ & 500 & 1,000 & 1500 & 0 & 1,000 & 1,500 & 2,000 \\
\hline $\mathrm{C} 06$ & -100 & -200 & 0 & 600 & 1,200 & 0 & 200 \\
\hline $\mathrm{C} 07$ & -100 & -200 & 300 & 100 & 200 & 300 & 400 \\
\hline
\end{tabular}

model in this research. GA, developed by Holland in 1975, mimics the natural selection process of evolution to search for optimal solutions according to the theory of survival-ofthe-fittest. GA is efficient and reliable for optimal or nearoptimal solutions in a short time [86]. GA has been widely employed to solve optimisation problems, particularly job sequencing, workshop layout, and resource allocation [16, 49, 87-89].

As shown in Figure 3, a set of possible solutions is randomly created as the initial population for the problem. Each solution is then calculated to obtain the fitness function value. New populations are generated by operators, namely, selection, crossover, and mutation, from the current population. After the iterations of fitness evaluation and application of genetic operators, an acceptable solution is generated when the number of iterations reaches the upper limit.

\section{Results and Discussion}

Based on consultation with industry experts, the data were composed as the inputs to the models.

4.1. Results of the Model for Scenario 1. The model for Scenario 1 of the proposed framework is demonstrated using an example as outlined below.

Table 3 summarises the volume, the delay for assembly, and the surcharges/incentives for the delivery delay. The delay for assembly is the number of days for which the general contractor has postponed the component's assembly activity. The delays are 3 days, 5 days, and 7 days for different components. The factory offers a delivery delay of up to 7 days and assigns a number to each delay as a surcharge/ incentive. The other inputs of the model include: (1) the capacity of on-site inventory, which is $150 \mathrm{~m}^{3}$; (2) the opportunity cost of on-site inventory, which is $\$ 10 / \mathrm{day} / \mathrm{m}^{3}$, and the price of the third-party inventory, which is $\$ 300 /$ day $/ \mathrm{m}^{3}$; and (3) double handling costs, which are $\$ 20 /$ time and $\$ 100 /$ time, respectively, for on-site inventory and thirdparty inventory.

The delivery is initially scheduled on the day when the assembly activity starts. As shown in Table 3, the assembly schedule is delayed; if the components are delivered as scheduled, the general contractor must pay an additional cost of $\$ 1,177,080$ for on-site or third-party inventory and double handling.

The GA solver deployed by MATLAB R2020a solves the optimisation model. The possible delivery delay's permutation is modelled as chromosomes, for which the lower bound and upper bound are set as 0 and 7, respectively. The parameters of MaxStallGenerations are set as 100, MaxGenerations as 300, and ConstraintTolerance as $1 e-6$. The other parameters, including selection, crossover, and mutation, take the default values. A fitness function is created to calculate the value of the objective function as expressed by equation (1) and another function models the nonlinear constraint of equation (6).

The upper portion of Figure 4 depicts the minimal total cost $(\$ 21,560)$, mean $(\$ 22,619.9)$, and the optimisation convergence curve. The lower portion shows the vector of [7 7405757777777777777 ], which is the permutation of the optimal delivery delay (by day) of the twenty components. Without the proposed optimisation, the general contractor must pay $\$ 1,075,500$ to account for the assembly delay. The optimised solution reduces the cost to $\$ 21,560$, which is a savings of $98 \%$.

Table 4 presents the optimised solutions for the delay and cost of the components. For example, the optimal solution of C01 is delaying delivery by 7 days, and thus paying no surcharges; and, by assembling the components on the delivery day, there is no additional cost for inventory. The optimal solution of $\mathrm{C} 04$ is for the components to be delivered as scheduled. The general contractor will store the components for 3 days, which incurs an opportunity cost of $\$ 1,200$ for inventory and \$20 for double handling. C05's optimal delivery is to be delayed by 5 days, and the general contractor can receive a $\$ 200$ incentive from the factory and store the components for 2 days on-site, which incurs an opportunity cost of $\$ 1,000$ for inventory and $\$ 20$ for double handling.

4.2. Sensitivity Analysis of On-Site Inventory Capacity for Scenario 1. On-site inventory is a significant resource as an indicator for the ability to handle asynchrony between component assembly and delivery, and plays a vital role in general contractors' decision-making. According to related literature and the interview with the industry, there is limited space for inventory on construction sites. The model is executed 14 additional times with different on-site inventory capacity values to investigate the relationship between optimisation performance and the on-site inventory capacity.

When the on-site inventory capacity increases from $0 \mathrm{~m}^{3}$ to $700 \mathrm{~m}^{3}$, the total cost of the delivering-as-scheduled scheme is reduced from $\$ 1,334,800$ to $\$ 44,800$, and the total cost of the delivering-as-optimised scheme is reduced from $\$ 36,700$ to $\$ 18,420$. The cost reduction ratio remains as high 


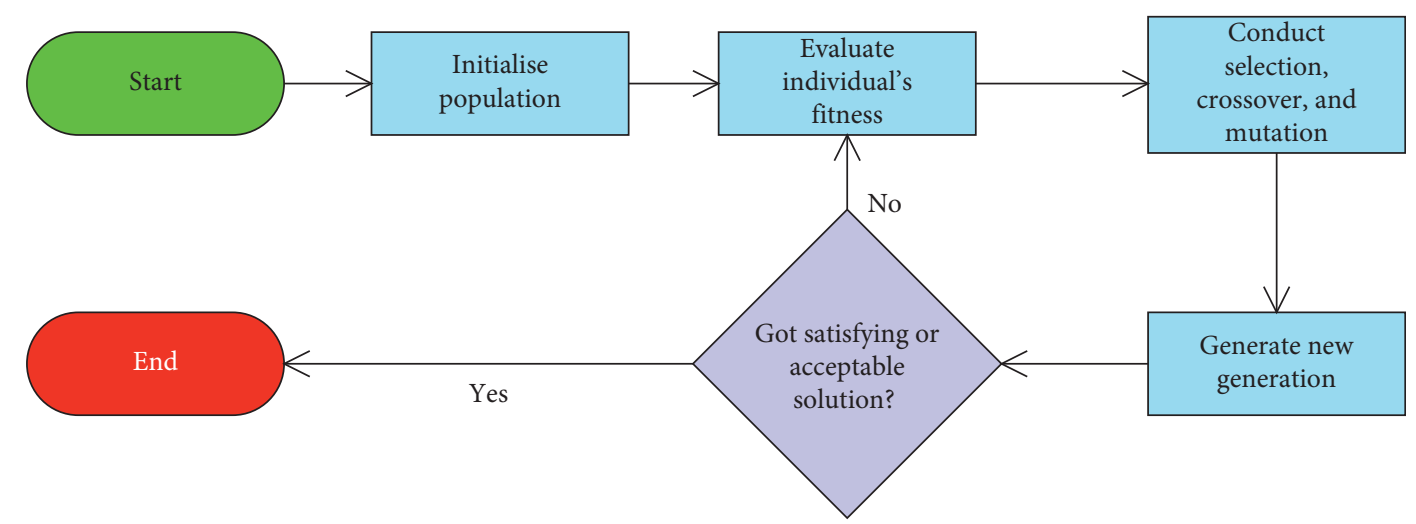

FIgURE 3: Genetic algorithm flow chart.

TABLE 3: Component delivery delays and surcharges/incentives*.

\begin{tabular}{|c|c|c|c|c|c|c|c|c|c|}
\hline \multirow{2}{*}{ Components } & \multirow{2}{*}{ Volume $\left(\mathrm{m}^{3}\right)$} & \multirow{2}{*}{ Delay for assembly (day) } & \multicolumn{7}{|c|}{ Surcharges/incentives for the delivery delays } \\
\hline & & & $1 \mathrm{~d}(\$)$ & $2 \mathrm{~d}(\$)$ & $3 \mathrm{~d}(\$)$ & $4 \mathrm{~d}(\$)$ & $5 \mathrm{~d}(\$)$ & $6 \mathrm{~d}(\$)$ & $7 \mathrm{~d}(\$)$ \\
\hline $\mathrm{C} 01$ & 10 & 7 & 100 & 200 & 300 & 0 & 0 & 0 & 0 \\
\hline $\mathrm{C} 02$ & 20 & 7 & -100 & 0 & 0 & 200 & 400 & 600 & 800 \\
\hline $\mathrm{C} 03$ & 30 & 7 & 300 & 600 & 900 & 0 & 600 & 900 & 1,200 \\
\hline $\mathrm{C} 04$ & 40 & 3 & 400 & 800 & 0 & 400 & 800 & 1,200 & 1,600 \\
\hline $\mathrm{C} 05$ & 50 & 7 & 500 & 1,000 & 1,500 & 0 & -200 & 1,500 & 2,000 \\
\hline C06 & 60 & 7 & 600 & 1,200 & 0 & 600 & 1,200 & 0 & 0 \\
\hline $\mathrm{C} 07$ & 10 & 5 & 100 & 200 & 300 & 100 & 200 & 300 & 400 \\
\hline $\mathrm{C} 08$ & 20 & 7 & 200 & 400 & 600 & 200 & 400 & 600 & 800 \\
\hline C09 & 30 & 7 & 300 & 600 & 900 & 0 & -100 & 900 & 1,200 \\
\hline C10 & 40 & 7 & 400 & 800 & 1,200 & 400 & 800 & 1,200 & 1,600 \\
\hline C11 & 50 & 7 & 500 & 1,000 & 0 & -200 & 1,000 & 1,500 & 2,000 \\
\hline $\mathrm{C} 12$ & 60 & 7 & 300 & 0 & -200 & 600 & 1,200 & 1,800 & 2,400 \\
\hline $\mathrm{C} 13$ & 10 & 7 & 100 & 200 & 300 & 100 & 200 & 300 & 400 \\
\hline C14 & 20 & 7 & 200 & 400 & 600 & 200 & 400 & 600 & 800 \\
\hline C15 & 30 & 7 & 300 & 600 & 0 & -200 & 600 & 900 & 1,200 \\
\hline C16 & 40 & 7 & 400 & 800 & 1,200 & 400 & 800 & 1,200 & 1,600 \\
\hline $\mathrm{C} 17$ & 50 & 7 & 500 & 1,000 & 1,500 & 500 & 1,000 & 1,500 & 2,000 \\
\hline C18 & 60 & 7 & 600 & 1,200 & 1,800 & 600 & 1,200 & 1,800 & 2,400 \\
\hline C19 & 10 & 7 & 100 & 200 & 300 & 100 & 200 & 300 & 400 \\
\hline $\mathrm{C} 20$ & 20 & 7 & 200 & 400 & 600 & 200 & 400 & 600 & 800 \\
\hline
\end{tabular}

*The underlined negative numbers represent incentives.

as $98 \%$ to $93 \%$ when the on-site inventory capacity is between $0 \mathrm{~m}^{3}$ and $550 \mathrm{~m}^{3}$ and decreases sharply when on-site inventory capacity is $600 \mathrm{~m}^{3}$ or less. The total cost of the delivering-as-scheduled scheme continues to decrease when on-site inventory capacity increases from $0 \mathrm{~m}^{3}$ to $700 \mathrm{~m}^{3}$ (see Figure 5).

When the on-site inventory capacity reaches $450 \mathrm{~m}^{3}$ or more, the total cost of the delivering-as-optimised scheme remains at $\$ 18,420$ because it can completely accommodate all the additional stock created by the assembly delay. When the on-site inventory capacity is 0 , the optimisation model can reduce the total cost by $97 \%$. When the on-site inventory varies from $50 \mathrm{~m}^{3}$ to $500 \mathrm{~m}^{3}$, the cost decreases by $98 \%$ to $95 \%$, showing a flat curve. When the on-site inventory reaches $550 \mathrm{~m}^{3}$ or greater, the reduction ratio drops to $93 \%$, $89 \%, 78 \%$, and $52 \%$, respectively. The total cost reduction ratio becomes sensitive to the on-site inventory capacity when the former increases to $600 \mathrm{~m}^{3}$ or more.
4.3. Sensitivity Analysis of Surcharge/Incentive Level for Scenario 1 . Total cost is a primary concern of general contractors. Surcharge/incentive level is an economic factor determined by the factories, making up the main part of the cost caused by delivery data change. The factor can significantly influence general contractors' decision-making. To investigate how the surcharge/incentive level impacts the total cost of the delivering-as-optimised scheme, the original surcharge/incentive values (see Table 3 ) are halved and increased to $150 \%$ to create another two sets of inputs. The model produces three cost curves with three surcharge/ incentive levels when the on-site inventory capacity increases from $0 \mathrm{~m}^{3}$ to $700 \mathrm{~m}^{3}$ (see Figure 6). A higher surcharge/incentive level produces a higher total cost when the on-site inventory capacity increases from $0 \mathrm{~m}^{3}$ to $500 \mathrm{~m}^{3}$; however, the cost differences gradually narrow. When the on-site inventory capacity reaches $550 \mathrm{~m}^{3}$ or greater, the curves of highest and medium surcharge/ 


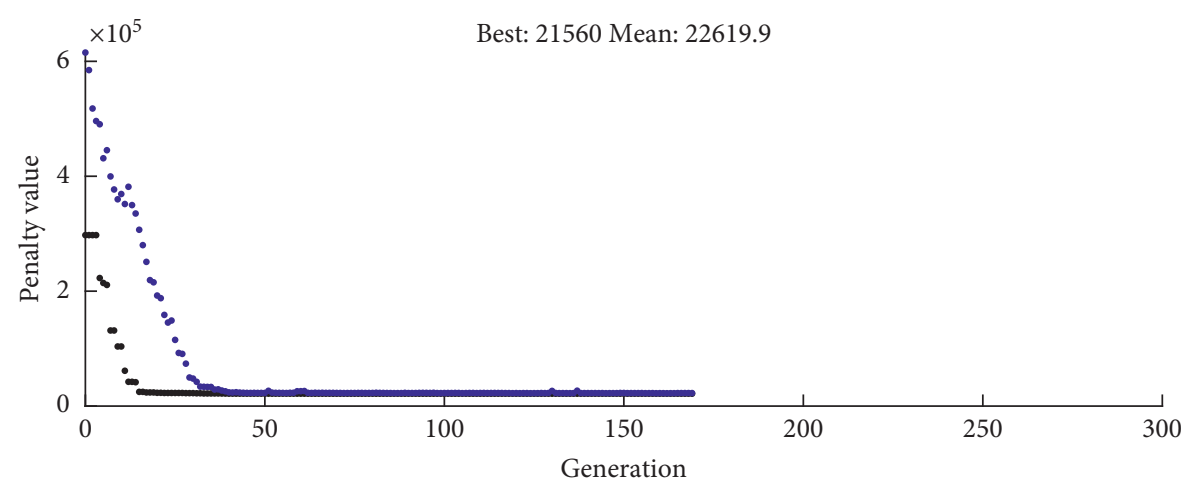

- Best penalty value

- Mean penalty value

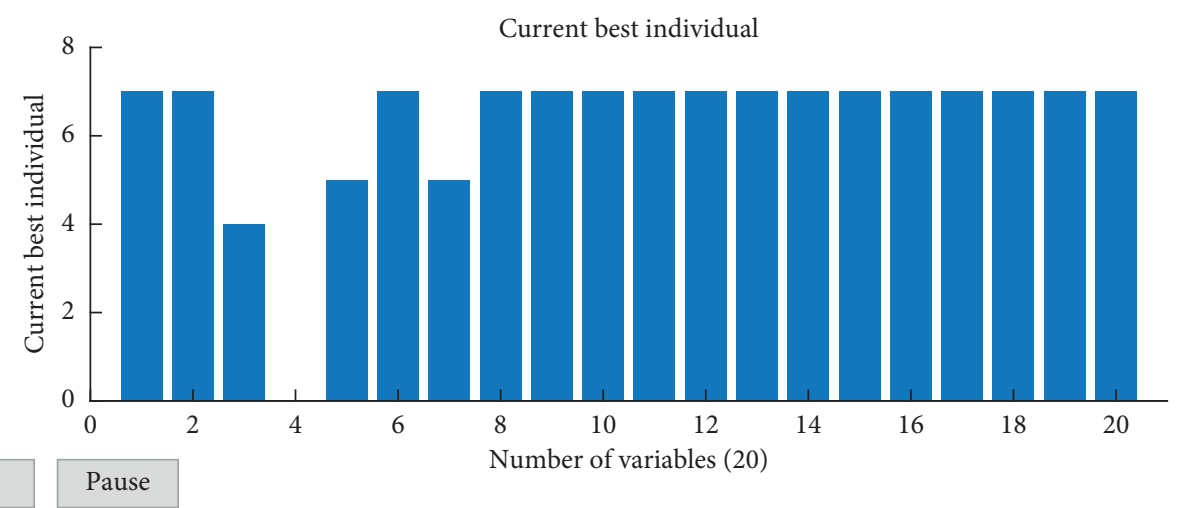

FIGURE 4: Optimisation results for scenario 1.

TABLE 4: Surcharge and incentive for optimised delivery delay of components.

\begin{tabular}{|c|c|c|c|c|c|c|}
\hline Components & $\begin{array}{l}\text { Volume } \\
\left(\mathrm{m}^{3}\right)\end{array}$ & $\begin{array}{l}\text { Delay for assembly } \\
\text { (day) }\end{array}$ & $\begin{array}{c}\text { Optimised delivery delay } \\
\text { (day) }\end{array}$ & $\begin{array}{c}\text { Surcharge/ } \\
\text { incentive (\$) }\end{array}$ & $\begin{array}{c}\text { Inventory cost } \\
(\$)\end{array}$ & $\begin{array}{l}\text { Double handling } \\
\text { cost }(\$)\end{array}$ \\
\hline $\mathrm{C} 01$ & 10 & 7 & 7 & 0 & 0 & 0 \\
\hline $\mathrm{C} 02$ & 20 & 7 & 7 & 800 & 0 & 0 \\
\hline $\mathrm{C} 03$ & 30 & 7 & 4 & 0 & 900 & 20 \\
\hline $\mathrm{C} 04$ & 40 & 3 & 0 & 0 & 1,200 & 20 \\
\hline $\mathrm{C} 05$ & 50 & 7 & 5 & -200 & 1,000 & 20 \\
\hline $\mathrm{C} 06$ & 60 & 7 & 7 & 0 & 0 & 0 \\
\hline $\mathrm{C} 07$ & 10 & 5 & 5 & 200 & 0 & 0 \\
\hline $\mathrm{C} 08$ & 20 & 7 & 7 & 800 & 0 & 0 \\
\hline $\mathrm{C} 09$ & 30 & 7 & 7 & 1,200 & 0 & 0 \\
\hline $\mathrm{C} 10$ & 40 & 7 & 7 & 1,600 & 0 & 0 \\
\hline $\mathrm{C} 11$ & 50 & 7 & 7 & 2,000 & 0 & 0 \\
\hline $\mathrm{C} 12$ & 60 & 7 & 7 & 2,400 & 0 & 0 \\
\hline $\mathrm{C} 13$ & 10 & 7 & 7 & 400 & 0 & 0 \\
\hline C14 & 20 & 7 & 7 & 800 & 0 & 0 \\
\hline C15 & 30 & 7 & 7 & 1,200 & 0 & 0 \\
\hline C16 & 40 & 7 & 7 & 1,600 & 0 & 0 \\
\hline $\mathrm{C} 17$ & 50 & 7 & 7 & 2,000 & 0 & 0 \\
\hline C18 & 60 & 7 & 7 & 2,400 & 0 & 0 \\
\hline C19 & 10 & 7 & 7 & 400 & 0 & 0 \\
\hline $\mathrm{C} 20$ & 20 & 7 & 7 & 800 & 0 & 0 \\
\hline
\end{tabular}




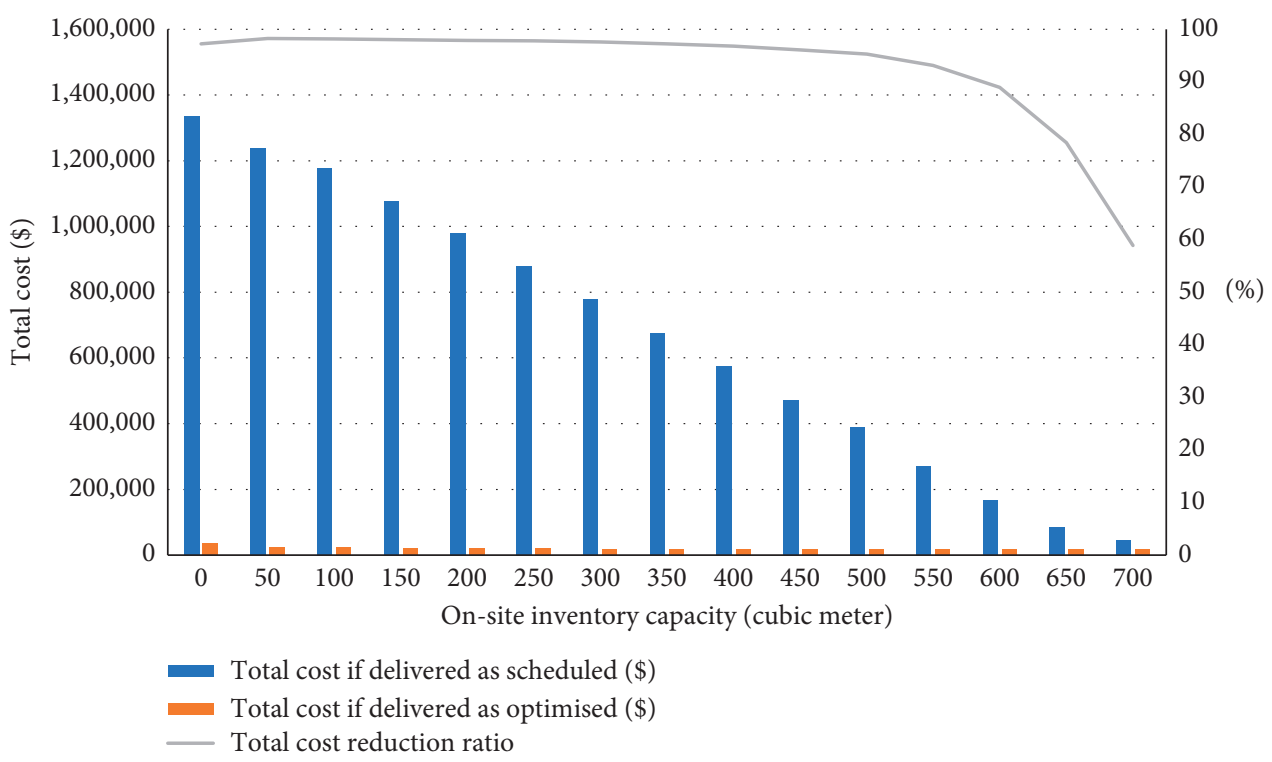

Figure 5: Total cost and reduction ratio for different on-site inventory capacities.

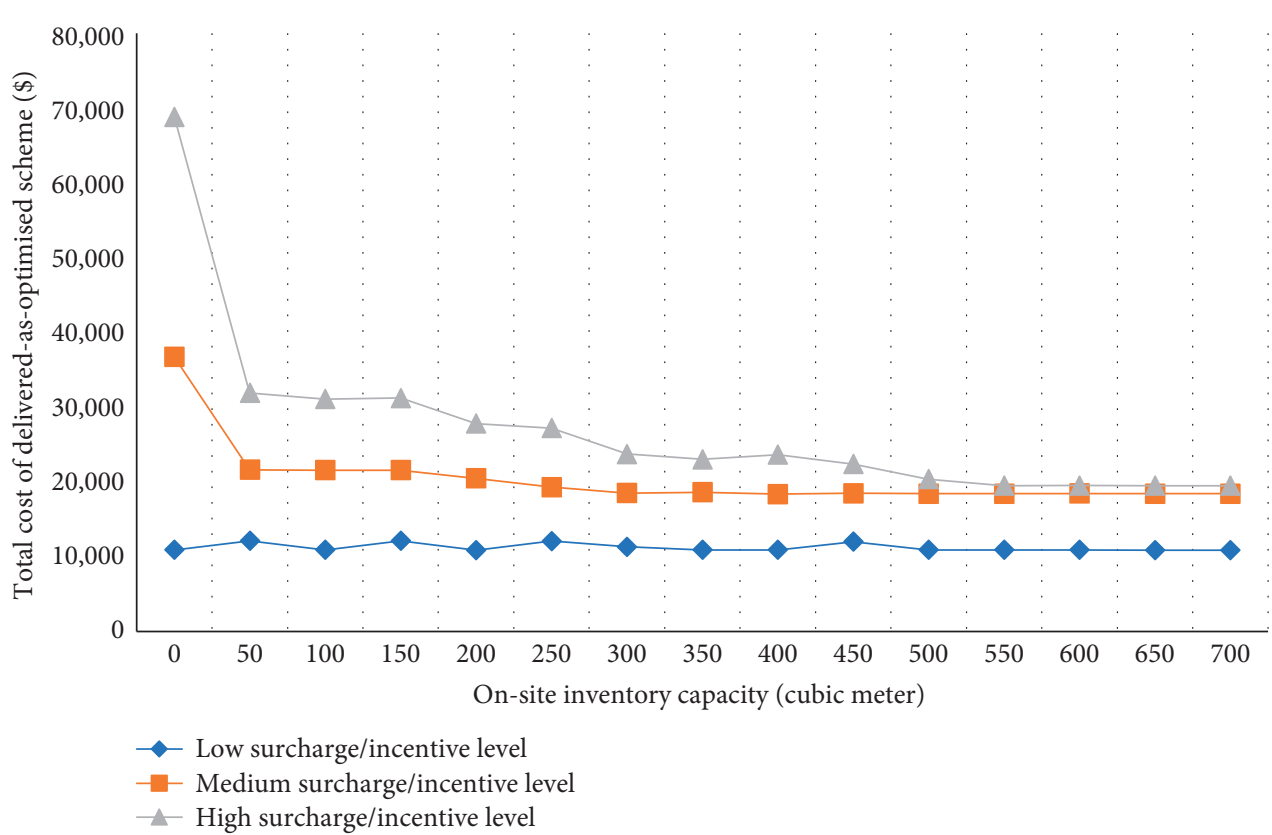

Figure 6: Total cost of the optimised delivery scheme at different surcharge/incentive levels.

incentive levels approximately coincide, implying that the surcharge/incentive level significantly impacts the model's performance when on-site inventory capacity is lower. The lowest curve is flat and remains fluctuating, indicating that delaying delivery is more likely to be used than storing in on-site inventory to manage assembly delay when the surcharge/incentive level is low.

In summary, the optimisation model can significantly reduce the total cost of delaying delivery if the general contractor has delayed assembly activities before the components are delivered. The total cost of the delivering-asoptimised scheme is sensitive to on-site inventory capacity when on-site inventory capacity is low. The level of surcharge/incentive is a sensitive factor for optimisation results when the on-site inventory capacity is low. It is common for general contractors to have limited on-site inventory, and the optimisation model is practical to reduce component delivery waste.

4.4. Results of the Model for Scenario 2. The model for Scenario 2 of the proposed framework is demonstrated using an example as follows. In this scenario, general contractors aim to maximise the revenue by changing the component 
TABLE 5: Delivery schedule and incentives or surcharges for delivery date changes.

\begin{tabular}{|c|c|c|c|c|c|c|c|c|c|}
\hline $\begin{array}{l}\text { Components/ } \\
\text { activity }\end{array}$ & $\begin{array}{c}\text { Duration } \\
\text { (day) }\end{array}$ & $\begin{array}{l}\text { Scheduled delivery } \\
\text { date }\end{array}$ & 1 day $(\$)$ & $\begin{array}{c}2 \text { days } \\
(\$)\end{array}$ & $\begin{array}{l}3 \text { days } \\
(\$)\end{array}$ & $\begin{array}{l}4 \text { days } \\
(\$)\end{array}$ & $\begin{array}{c}5 \text { days } \\
(\$)\end{array}$ & $\begin{array}{c}6 \text { days } \\
(\$)\end{array}$ & 7 days (\$) \\
\hline C01 & 1 & 3 & 100 & 200 & 300 & 0 & 0 & 0 & -100 \\
\hline $\mathrm{C} 02$ & 2 & 4 & 100 & 0 & 0 & 200 & 400 & 600 & -800 \\
\hline $\mathrm{C} 03$ & 3 & 8 & 300 & -600 & 300 & 0 & 600 & 900 & 1,200 \\
\hline $\mathrm{C} 04$ & 4 & 6 & 400 & 800 & 0 & 400 & 800 & 1,200 & $-1,600$ \\
\hline $\mathrm{C} 05$ & 1 & 11 & 500 & 1,000 & 1,500 & 0 & 1,000 & 1,500 & 2,000 \\
\hline $\mathrm{C} 06$ & 2 & 14 & -100 & -200 & 0 & 600 & 1,200 & 0 & 200 \\
\hline $\mathrm{C} 07$ & 3 & 12 & -100 & -200 & 300 & 100 & 200 & 300 & 400 \\
\hline $\mathrm{C} 08$ & 4 & 16 & -100 & -200 & 600 & 200 & 400 & 600 & 800 \\
\hline C09 & 1 & 17 & -100 & -200 & 900 & 0 & 600 & 900 & 1,200 \\
\hline $\mathrm{C} 10$ & 2 & 18 & 100 & 200 & 1,200 & 400 & 800 & 1,200 & 1,600 \\
\hline C11 & 2 & 0 & -100 & 1,000 & 0 & 500 & 1,000 & 1,500 & 2,000 \\
\hline $\mathrm{C} 12$ & 2 & 2 & -100 & -200 & 300 & 600 & 1,200 & 1,800 & 2,400 \\
\hline C13 & 2 & 4 & -100 & -200 & 300 & 100 & 200 & 300 & 400 \\
\hline C14 & 2 & 6 & -100 & -200 & 600 & 200 & 400 & 600 & 800 \\
\hline C15 & 2 & 8 & 300 & 300 & 0 & 300 & 600 & 900 & 1,200 \\
\hline C16 & 2 & 10 & -100 & -200 & 1,200 & 400 & 800 & 1,200 & 1,600 \\
\hline $\mathrm{C} 17$ & 2 & 12 & -100 & -200 & 1,500 & 500 & 1,000 & 1,500 & 2,000 \\
\hline C18 & 2 & 16 & -100 & -200 & 1,800 & 600 & 1,200 & 1,800 & 2,400 \\
\hline C19 & 2 & 18 & -100 & -100 & 300 & 100 & 200 & 300 & 400 \\
\hline $\mathrm{C} 20$ & 2 & 20 & 200 & 400 & 600 & 200 & 400 & 600 & 800 \\
\hline End & 0 & 22 & 0 & 0 & 0 & 0 & 0 & 0 & 0 \\
\hline
\end{tabular}

delivery date and receiving the incentives when the change is acceptable. The execution of the model for Scenario 2 is also based on the data presented in Table 5, which summarises the duration, scheduled delivery date, and the surcharges/ incentives for the delivery change of components. The components and corresponding assembly activities are numbered sequentially and the start of the fictitious component named "End" represents the completion of the project. The additional input is 3 days, the maximum tolerable delay of the start date of "End," thereby limiting the latest completion date of the project. MATLAB GA solver does not offer a built-in method to maximise the objective. Therefore, the model is solved by minimising the negative of the object function.

Similar to Scenario 1, the GA solver found in MATLAB R2020a solves the optimisation model. The possible delivery delay's permutation is modelled as chromosomes, for which the lower bound and upper bound are set as 0 and 7, respectively. The parameters of MaxStallGenerations are set as 100, MaxGenerations as 300, and ConstraintTolerance as $1 e-6$. The other parameters, including selection, crossover, and mutation, take the default values. A fitness function to minimise the value of the negative objective is expressed by equation (7) and another function models the nonlinear constraints of equations (8)- (11). The upper portion of Figure 7 illustrates the maximum total revenue of $\$ 1,800$ and the optimisation convergence curve. The lower portion shows the vector of $\left[\begin{array}{llllllllllllllllllll}0 & 0 & 0 & 7 & 0 & 0 & 2 & 2 & 0 & 0 & 1 & 2 & 2 & 2 & 0 & 0 & 1 & 2 & 1 & 0\end{array}\right]$, which is the permutation of the optimal delivery delay (by day) of the twenty components. However, the revised delivery schedule is not simply the original schedule plus optimal delivery delay because of the constraints expressed in equations (8)-(11). The best total revenue is $\$ 1,800$. However, the best is shown as $-1,800$ because maximising the objective function is converted to minimising the negative objective function. The lower part of the figure shows the optimal delivery delay.

As presented in Table 6, the revenues are calculated with the actual delay, and the total revenue is $\$ 1,800$. The actual delay of "End" activity is 3 days, satisfying the constraint.

When the delay tolerance of the "End" activity is 2 days, the total revenue is $\$ 1,400$. However, not every delay tolerance creates a solution. If the "End" activity's delay is 1 day or less, the optimisation model will terminate rather than give a revised delivery schedule when the number of iterations reaches the parameter of MaxStallGenerations.

Apart from "marking" the start date of the last activity, the model can also "mark" another activity's delay tolerance as the optimisation's constraint. Table 7 presents the results of 80 repeated executions with the "marked" activity changing from "C01" to "C20" and the delay tolerance changing from 0 to 3 days. In the table, the precondition is the project's delay tolerance of 3 days. The first row shows that the total revenue is $\$ 1,800$ when the activity C01's delay tolerance is 0 days, and the revised delivery schedule is expressed with the vector of [3 48131117141919191468 10121418202325 ]. The last four rows in the table show the result when the "marked" activity is C20. The model is unsolvable when the delay tolerance is 1 days or 0 days. The total revenue is $\$ 1,400$ and $\$ 1,800$ when the delay tolerance is 2 days or 3 days, respectively.

The results indicate that for general contractors, trading schedule flexibility for incentives is feasible. In construction 


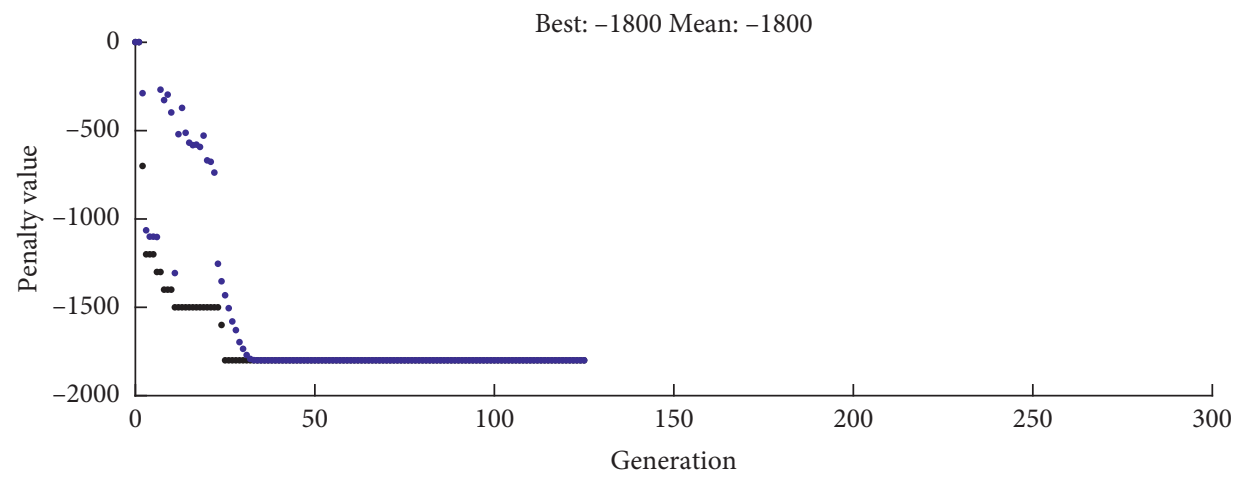

- Best penalty value

- Mean penalty value

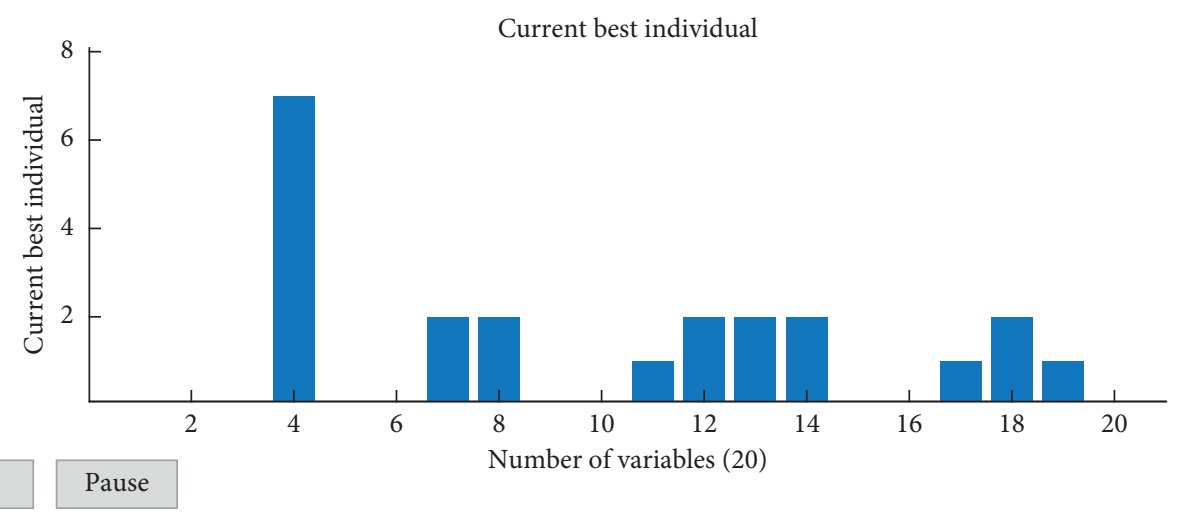

FIGURE 7: Optimisation results for scenario 2.

TABle 6: Result with the "end" activity's delay tolerance being 3 days.

\begin{tabular}{|c|c|c|c|c|c|c|c|c|c|c|c|c|c|c|c|c|c|c|c|c|c|}
\hline Component & $\mathrm{C} 01$ & $\mathrm{C} 02$ & $\mathrm{C} 03$ & $\mathrm{C} 04$ & C05 & C06 & C07 & C08 & C09 & C10 & C11 & $\mathrm{C} 12$ & $\mathrm{C} 13$ & C14 & $\mathrm{C} 15$ & $\mathrm{C} 16$ & $\mathrm{C} 17$ & $\mathrm{C} 18$ & C19 & C20 & End \\
\hline & 3 & 4 & 8 & 6 & 11 & 14 & 12 & 16 & 17 & 18 & 0 & 2 & 4 & 6 & & & & 16 & & & 22 \\
\hline & 3 & 4 & 8 & 13 & & & 14 & 19 & 19 & 19 & 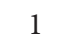 & 4 & 6 & & & & & & & & 25 \\
\hline $\begin{array}{l}\text { Actual delay } \\
\text { (day) }\end{array}$ & 0 & 0 & 0 & 7 & 0 & 3 & 2 & 3 & 2 & 1 & 1 & 2 & 2 & 2 & 2 & 2 & 2 & 2 & 2 & 3 & 3 \\
\hline Revenue (\$) & 0 & 0 & 0 & 1600 & 0 & 0 & 200 & -600 & 200 & -100 & 100 & 200 & 200 & 200 & -300 & 200 & 200 & 200 & 100 & -600 & 0 \\
\hline
\end{tabular}

The revenue is calculated with the actual delay.

engineering practice, the proposed model can help general contractors to trade their schedule flexibility for incentives offered by factories, thereby reducing component delivery waste and the cost of entire projects.

4.5. Applicability for Solving Problems in Complex Scenarios. The information platform can serve multiple stakeholders in many-to-many scenarios (Figure 8 ). However, any specific transaction actually occurs in a one-to-one manner, as shown in Figure 2, due to that any transaction is based on a specific contract. Each factory independently releases surcharge/incentive for delivery date change according to its resource constraints, and each general contractor independently decides to accept the components on schedule or change the delivery date based on the total cost. More specifically, one general contractor interacts with one factory over a specific contract through the information platform. 


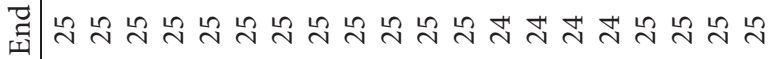

ปิ

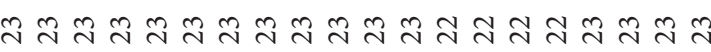

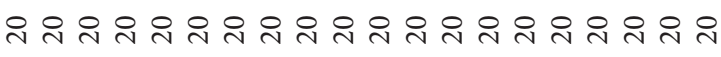
$\stackrel{\infty}{\rightarrow} \stackrel{\infty}{\sim} \stackrel{\infty}{\sim} \stackrel{\infty}{\sim} \stackrel{\infty}{\sim} \stackrel{\infty}{\sim} \stackrel{\infty}{\sim} \stackrel{\infty}{\sim} \stackrel{\infty}{\sim} \stackrel{\infty}{\sim} \stackrel{\infty}{\sim} \stackrel{\infty}{\sim}$

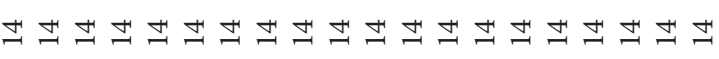
$\simeq \simeq \simeq \simeq \simeq \simeq \simeq \simeq \simeq \simeq \simeq \simeq \simeq \simeq \simeq \simeq \simeq \simeq \simeq \cong$ 으으으으으으으으으으으으으으으으으으으으

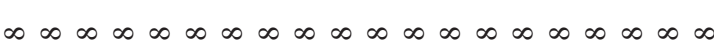

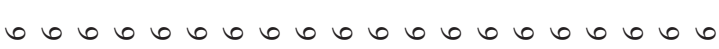

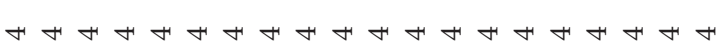
$-1-10000000000000000$

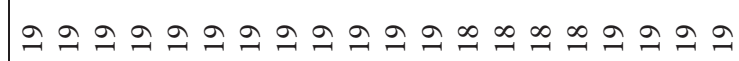

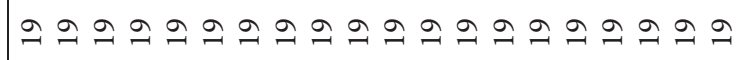

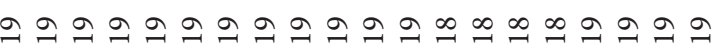

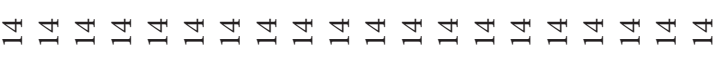

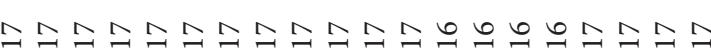

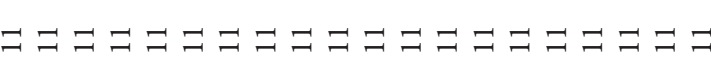

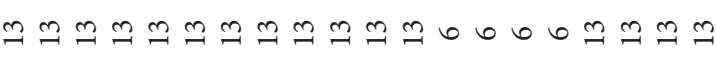
$\infty \infty \infty \infty \infty \infty \infty \infty \infty \infty \infty \infty \infty \infty \infty \infty \infty \infty$

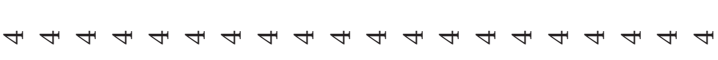

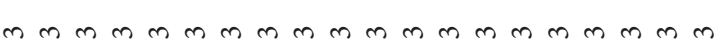

\section{৪৪৪৪৪৪৪৪৪৪৪৪৪৪৪৪৪৪৪৪}

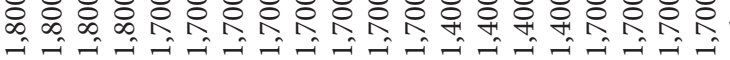

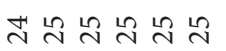

สิก

ํํํํํำำำ $\stackrel{\infty}{\sim} \stackrel{\infty}{\sim} \stackrel{\infty}{\sim}$

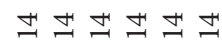

$\simeq \simeq \simeq \simeq \simeq \simeq$

으으으으으으

$\infty \infty \infty \infty \infty \infty$

666666

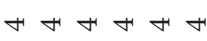

$0-0000$

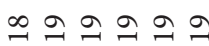

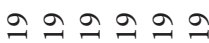

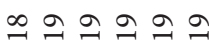

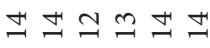

으ㄷㅗㅗㅗㄱ

$\exists \Xi \exists \Xi コ \Xi$

므묘묘

$\infty \infty \infty \infty \infty \infty$

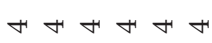

$n n m m n n$

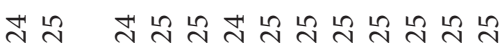

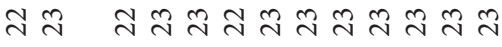

유유 유유유유유유유유유 $\stackrel{\infty}{\sim} \stackrel{\infty}{\sim} \stackrel{\infty}{\sim} \stackrel{\infty}{\sim} \stackrel{\infty}{\sim} \stackrel{\infty}{\sim} \stackrel{\infty}{\sim} \stackrel{\infty}{\sim}$

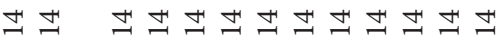

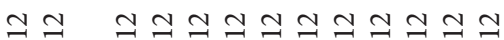
으오 으으으으으으으으으으으 $\infty \infty \quad \infty \infty \infty \infty \infty \infty \infty \infty \infty \infty \infty$ 660666666666

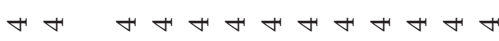

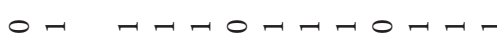

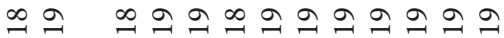

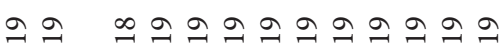

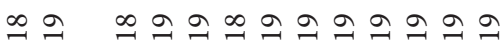

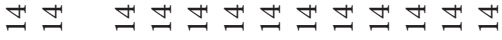

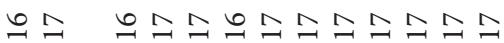
$\exists \Xi \quad \exists \Xi \Xi \Xi \Xi \Xi \Xi \Xi \Xi \Xi \Xi$

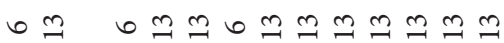
$\infty \infty \quad \infty \infty \infty \infty \infty \infty \infty \infty \infty \infty \infty$

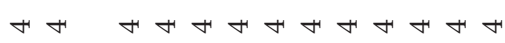

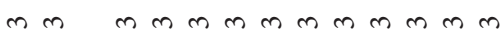




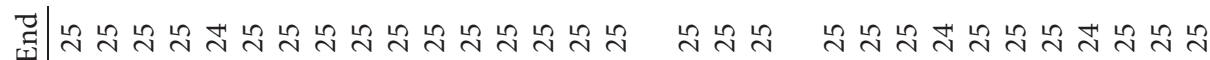

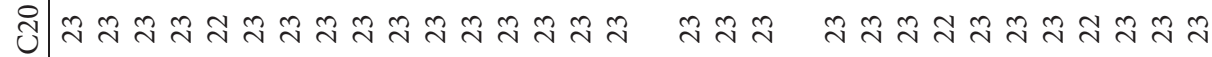

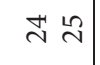

తे

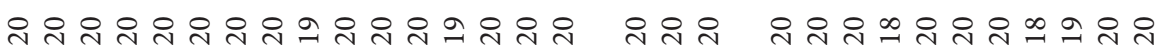

$\stackrel{\infty}{\cup}$

$\stackrel{\infty}{\rightarrow} \stackrel{\infty}{\rightarrow} \stackrel{\infty}{\rightarrow} \stackrel{\infty}{\rightarrow} \rightarrow$

जิ

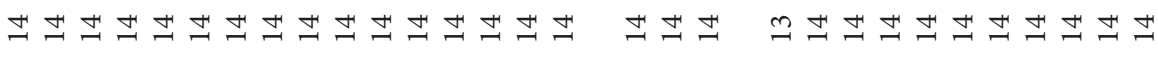

$\simeq \simeq \simeq \simeq \simeq \simeq \simeq \simeq \simeq \simeq \simeq \simeq \simeq \simeq บ$

un

으으으으 $\infty$ 으으으 $\infty \infty$ 으으 $\infty \infty$ 으

$\exists \simeq \simeq$

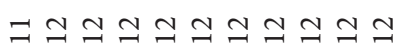

$\stackrel{\uplus}{U} \infty$

$\infty \infty \infty \infty \vee \infty \infty \infty \vee \bullet \infty \infty \vee 6 \infty$

$a$ 오으

$a$ 으으 $\infty$ 으으으으으으으

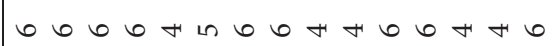

$\wedge \infty \infty$

$\wedge \infty \infty \vee \infty \infty \infty \infty \infty \infty$

in 66

in 0046060606

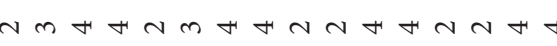

$n \rightarrow r$

$m a t h t a t h t a t h$

O-1- $-00-100-100-$

or-

०ー-

Ia a a a a a a a a a

aㅇ

으음으으으음

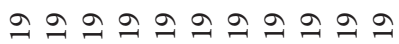

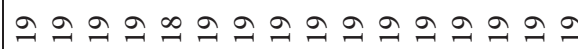

으음

으으으으으응

ऽิ

むむむむむむむむむむむむむむむ

도돋NヘN

サす

むむさむむむさむむむむ

드드ㅇㅡㅡㅡㅡㅡㅡㅡㄷㅡ

๖ำ

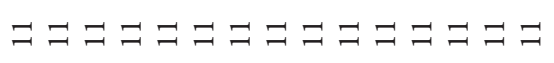

ঠ)

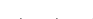

ヨコココココココココ

ชิ

$\infty \infty \infty \infty \infty \infty \infty \infty \infty \infty \infty \infty \infty \infty$

$m m m$

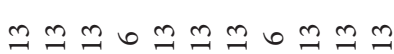

ชิ

$\dot{\delta}$

$m$

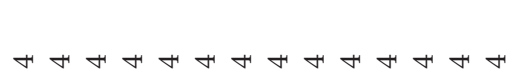

$\infty \infty \infty \infty \infty \infty \infty \infty \infty \infty$

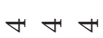

$44 t 4 t h 4 t h t h$

$m m m$

$m m n n m m m n m$

क्ञ

:

৪৪৪৪৪৪৪৪৪৪৪৪৪৪৪৪

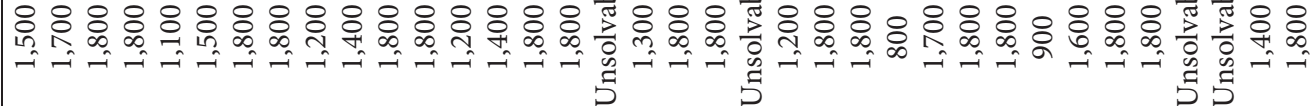




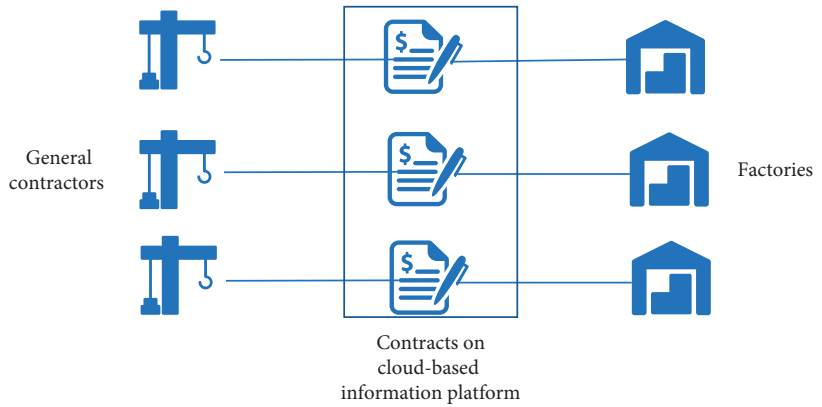

FIGURE 8: The information platform with each transaction processed in a one-to-one manner.

\section{Conclusions and Limitations}

Off-site construction has many advantages compared with traditional construction and is increasingly gaining in popularity. The fragmentation of prefabrication and assembly produces not only higher quality, higher efficiency, and shorter project duration but also a more complex supply chain, which creates component delivery waste when the original delivery schedule becomes nonoptimal for either the general contractor or the factory. The just-in-time method has been widely adopted to reduce waste in the manufacturing industry and the ready-mix concrete delivery in the construction industry. Lack of a practical compensation system leads general contractors and factories to deal with uncertainties independently rather than sharing resources to achieve just-in-time delivery. The research presented in this paper proposes a dynamic compensation mechanism to encourage both parties to reduce component delivery waste. Two optimisation models are created to facilitate both parties to attain optimal decision-making. The model for Scenario 1 can significantly decrease the total cost caused by component delivery when contractors postpone their assembly activities. When on-site inventory capacity is low, the level of surcharge/ incentive and the unit cost of third-party inventory are sensitive factors for optimisation results. The model for Scenario 2 helps general contractors to trade their duration flexibility for incentives offered by factories. The models can enable both parties to reduce component delivery waste when either side has the impetus to change the original component delivery schedule. The contributions of this work include (1) identifying component delivery waste in off-site construction and (2) proposing a dynamic compensation solution to achieve just-in-time delivery. This study has several limitations. The other restraints, such as worker, equipment, and transportation, are not taken as parameters in the present research. More inputs to the model and an improved genetic algorithm should be considered in future research.

\section{Data Availability}

The data used to support the findings of this study are included within the article.

\section{Conflicts of Interest}

The authors declare that they have no conflicts of interest.

\section{References}

[1] W. Pan and R. Sidwell, "Demystifying the cost barriers to offsite construction in the UK," Construction Management and Economics, vol. 29, no. 11, pp. 1081-1099, 2011.

[2] Z. Li, G. Q. Shen, and X. Xue, "Critical review of the research on the management of prefabricated construction," Habitat International, vol. 43, pp. 240-249, 2014.

[3] H. Liu, Z. Lei, H. X. Li, and M. Al-Hussein, "An automatic scheduling approach: building information modeling-based onsite scheduling for panelized construction," in Proceedings of the Construction Research Congress 2014, pp. 1666-1675, American Society of Civil Engineers, Atlanta, Georgia, May 2014.

[4] M. Kamali and K. Hewage, "Life cycle performance of modular buildings: a critical review," Renewable and Sustainable Energy Reviews, vol. 62, pp. 1171-1183, 2016.

[5] C. Goodier and A. Gibb, "Future opportunities for offsite in the UK," Construction Management and Economics, vol. 25, no. 6, pp. 585-595, 2007.

[6] I. Y. Wuni, G. Q. P. Shen, and A. T. Mahmud, "Critical risk factors in the application of modular integrated construction: a systematic review," International Journal of Construction Management, pp. 1-15, 2019.

[7] L. Luo, G. Qiping Shen, G. Xu, Y. Liu, and Y. Wang, "Stakeholder-associated supply chain risks and their interactions in a prefabricated building project in Hong Kong," Journal of Management in Engineering, vol. 35, no. 2, Article ID 05018015, 2019.

[8] F. Costa, A. Denis Granja, A. Fregola, F. Picchi, and A. Portioli Staudacher, "Understanding relative importance of barriers to improving the customer-supplier relationship within construction supply chains using DEMATEL technique," Journal of Management in Engineering, vol. 35, no. 3, Article ID 04019002, 2019.

[9] F. Mellado and E. C. W. Lou, "Building information modelling, lean and sustainability: an integration framework to promote performance improvements in the construction industry," Sustainable Cities and Society, vol. 61, Article ID 102355, 2020.

[10] L.-z. Luo, C. Mao, L.-y. Shen, and Z.-d. Li, "Risk factors affecting practitioners' attitudes toward the implementation of an industrialized building system," Engineering, Construction and Architectural Management, vol. 22, no. 6, pp. 622-643, 2015.

[11] N. G. Blismas, M. Pendlebury, A. Gibb, and C. Pasquire, "Constraints to the use of off-site production on construction projects," Architectural Engineering and Design Management, vol. 1, no. 3, pp. 153-162, 2005. 
[12] W. Pan, A. G. F. Gibb, and A. R. J. Dainty, "Perspectives of UK housebuilders on the use of offsite modern methods of construction," Construction Management and Economics, vol. 25, no. 2, pp. 183-194, 2007.

[13] P.-Y. Hsu, P. Angeloudis, and M. Aurisicchio, "Optimal logistics planning for modular construction using two-stage stochastic programming," Automation in Construction, vol. 94, pp. 47-61, 2018.

[14] M. Sambasivan and Y. W. Soon, "Causes and effects of delays in Malaysian construction industry," International Journal of Project Management, vol. 25, no. 5, pp. 517-526, 2007.

[15] H. X. Li, M. Al-Hussein, Z. Lei, and Z. Ajweh, "Risk identification and assessment of modular construction utilizing fuzzy analytic hierarchy process (AHP) and simulation," Canadian Journal of Civil Engineering, vol. 40, no. 12, pp. 1184-1195, 2013.

[16] Z. Liu, Y. Zhang, and M. Li, "Integrated scheduling of readymixed concrete production and delivery," Automation in Construction, vol. 48, pp. 31-43, 2014.

[17] M. Arashpour and M. Arashpour, "Analysis of workflow variability and its impacts on productivity and performance in construction of multistory buildings," Journal of Management in Engineering, vol. 31, no. 6, Article ID 04015006, 2015.

[18] Z. Ren, G. Q. Shen, and X. L. Xue, "Failure caused by inappropriate construction methods: an expensive lesson," Journal of Management in Engineering, vol. 29, no. 1, pp. 25-34, 2013.

[19] C.-H. Ko, "An integrated framework for reducing precast fabrication inventory," Journal of Civil Engineering and Management, vol. 16, no. 3, pp. 418-427, 2010.

[20] G. Polat, D. Arditi, G. Ballard, and U. Mungen, "Economics of on-site vs. off-site fabrication of rebar," Construction Management and Economics, vol. 24, no. 11, pp. 1185-1198, 2006.

[21] P. Yung and B. Yip, "Construction quality in China during transition: a review of literature and empirical examination," International Journal of Project Management, vol. 28, no. 1, pp. 79-91, 2010.

[22] T. Ohno, Toyota Production System: Beyond Large-Scale Production, Productivity Press, Portland, OR, USA, 1988.

[23] T. Bølviken, J. Rooke, and L. Koskela, "The wastes of production in construction-a TFV based taxonomy," in Proceedings of the 22nd Annual Conference of the International Group for Lean Construction: Understanding and Improving Project Based Production, IGLC 2014, B. T. Kalsaas, L. Koskela, and T. A. Saurin, Eds., The International Group for Lean Construction, Oslo, Norway, pp. 811-822, June 2014.

[24] J. K. Liker, The Toyota Way: 14 Management Principles from the World's Greatest Manufacturer, McGraw-Hill Education, New York, NY, USA, 2004.

[25] D. Towill, "Handshakes around the world [Toyota production system]," Manufacturing Engineer, vol. 85, no. 1, pp. 20-25, 2006.

[26] L. S. Pheng and G. Shang, "The application of the just-in-time philosophy in the Chinese construction industry," Journal of Construction in Developing Countries, vol. 16, no. 1, pp. 91111, 2011.

[27] C.-C. Yang and K.-J. Yang, "An integrated model of the Toyota production system with total quality management and people factors," Human Factors and Ergonomics in Manufacturing \& Service Industries, vol. 23, no. 5, pp. 450461, 2013.

[28] A. Hall, "A structure for organizational learning," The Journal of Technology Transfer, vol. 20, no. 3-4, pp. 11-19, 1995.
[29] H. Sakai and K. Amasaka, "TPS-LAS model using process layout CAE system at Toyota: advanced TPS, key to global production strategy New JIT," Journal of Advanced Manufacturing Systems, vol. 5, no. 2, pp. 127-140, 2006.

[30] K. Amasaka, Toyota: Production System, Safety Analysis and Future Directions, Nova Science Publishers, Inc., New York, NY, USA, 2017.

[31] A. Chiarini, C. Baccarani, and V. Mascherpa, "Lean production, toyota production system and kaizen philosophy," The TQM Journal, vol. 30, no. 4, pp. 425-438, 2018.

[32] Y. Monden, Toyota Production System: An Integrated Approach to Just-In-Time, Industrial Engineering and Management Press, Norcross, GA, USA, 2nd edition, 1993.

[33] G. Shang and S. P. Low, Lean Construction Management: The Toyota Way, Springer, Singapore, 2014.

[34] C. T. Pérez and D. Costa, Developing a Taxonomy of Transportation Waste in Construction Production Processes, Built Environment Project and Asset Management, England, UK, 2018.

[35] L. Koskela, An Exploration towards a Production Theory and Its Application to Construction, VTT Technical Research Centre of Finland, VTT Building Tecnology, Wellington, New Zealand, 2000.

[36] I. D. Tommelein and E. Y. Li, "Just-in-time concrete delivery: mapping alternatives for vertical supply chain integration," in Proceedings of the 7th International Group for Lean Construction IGLC 1999, Univ. of Berkeley, Berkeley, CA, USA, July 1999.

[37] R. J. Vokurka and R. A. Davis, Just-in-Time: The Evolution of a Philosophy, American Production and Inventory Control Society Inc., Chicago, IL, USA, 1996.

[38] I. D. Tommelein, "Pull-driven scheduling for pipe-spool installation: simulation of lean construction technique," Journal of Construction Engineering and Management, vol. 124, no. 4, pp. 279-288, 1998.

[39] L. Koskela, A. Ferrantelli, J. Niiranen, E. Pikas, and B. Dave, "Epistemological explanation of lean construction," Journal of Construction Engineering and Management, vol. 145, no. 2, Article ID 04018131, 2018.

[40] L. Koskela, G. Howell, G. Ballard, and I. Tommelein, The Foundations of Lean Construction, Design and Construction, CRC Press, Boca Raton, FL, USA, 2007.

[41] L. Koskela, "Moving-on-beyond lean thinking," Lean Construction Journal, vol. 1, no. 1, pp. 24-37, 2004.

[42] S. A. A. Hosseini, A. Nikakhtar, K. Y. Wong, and A. Zavichi, "Implementing lean construction theory into construction processes' waste management," in Proceedings of the International Conference on Sustainable Design and Construction 2011: Integrating Sustainability Practices in the Construction Industry, ICSDC 2011, pp. 414-420, Kansas City, MO, April 2012.

[43] R. Vrijhoef and L. Koskela, "The four roles of supply chain management in construction," European Journal of Purchasing and Supply Management, vol. 6, no. 3-4, pp. 169-178, 2000.

[44] P. Wu and S. P. Low, "Barriers to achieving green precast concrete stock management-a survey of current stock management practices in Singapore," International Journal of Construction Management, vol. 14, no. 2, pp. 78-89, 2014.

[45] P. Wu and Y. Feng, "Identification of non-value adding activities in precast concrete production to achieve low-carbon production," Architectural Science Review, vol. 57, no. 2, pp. 105-113, 2014. 
[46] D. D. Viana, I. R. Bulhões, and C. T. Formoso, "Guidelines for integrated planning and control of engineer-to-order prefabrication systems," in Proceedings of the 21st Annual Conference of the International Group for Lean Construction 2013, IGLC 2013, C. T. Formoso and P. Tzortzopoulos, Eds., The International Group for Lean Construction, Fortaleza, Brazil, pp. 486-495, August 2013.

[47] L. S. Pheng and C. J. Chuan, "Just-in-time management in precast concrete construction: a survey of the readiness of main contractors in Singapore," Integrated Manufacturing Systems, vol. 12, no. 6-7, pp. 416-429, 2001.

[48] Y. Zhai, R. Y. Zhong, and G. Q. Huang, "Buffer space hedging and coordination in prefabricated construction supply chain management," International Journal of Production Economics, vol. 200, pp. 192-206, 2018.

[49] Y. Fang and S. T. Ng, "Genetic algorithm for determining the construction logistics of precast components," Engineering, Construction and Architectural Management, vol. 26, no. 15, 2019.

[50] Y. Zhang, G. Fan, Z. Lei, and S. Han, "Lean-based diagnosis and improvement for offsite construction factory manufacturing facilities," in Proceedings of the ISARC 2016-33rd International Symposium on Automation and Robotics in Construction, pp. 1090-1098, Auburn, AL, USA, July 2016.

[51] Y. Zhang, Z. Lei, S. Han, A. Bouferguene, and M. Al-Hussein, "Process-oriented framework to improve modular and offsite construction manufacturing performance," Journal of Construction Engineering and Management, vol. 146, no. 9, Article ID 04020116, 2020.

[52] J. L. Householder and H. E. Rutland, "Who owns float?" Journal of Construction Engineering and Management, vol. 116, no. 1, pp. 130-133, 1990.

[53] L.-S. Kang, H.-S. Moon, C.-H. Min, S.-K. Kim, and H. S. Kim, "Developing an active resource allocation algorithm considering resource supply and demand in a construction site," KSCE Journal of Civil Engineering, vol. 19, no. 1, pp. 17-27, 2015.

[54] G. K. Rand, "Elements of project management: plan, schedule, and control (2nd edition)," Journal of the Operational Research Society, vol. 44, 1993.

[55] C. Z. Li, J. Hong, F. Xue, G. Q. Shen, X. Xu, and M. K. Mok, "Schedule risks in prefabrication housing production in Hong Kong: a social network analysis," Journal of Cleaner Production, vol. 134, pp. 482-494, 2016.

[56] J. Gosling and M. M. Naim, "Engineer-to-order supply chain management: a literature review and research agenda," International Journal of Production Economics, vol. 122, no. 2, pp. 741-754, 2009.

[57] T. Davis, "Effective supply chain management," Sloan Management Review, vol. 34, p. 35, 1993.

[58] J. Gosling, M. Naim, and D. Towill, "Identifying and categorizing the sources of uncertainty in construction supply chains," Journal of Construction Engineering and Management, vol. 139, no. 1, pp. 102-110, 2013.

[59] M. H. Mello, J. O. Strandhagen, and E. Alfnes, "Analyzing the factors affecting coordination in engineer-to-order supply chain," International Journal of Operations \& Production Management, vol. 35, no. 7, pp. 1005-1031, 2015.

[60] F. Salvador, M. Rungtusanatham, C. Forza, and A. Trentin, "Mix flexibility and volume flexibility in a build-to-order environment," International Journal of Operations \& Production Management, vol. 27, no. 11, pp. 1173-1191, 2007.
[61] M. Holweg, "The three dimensions of responsiveness," International Journal of Operations \& Production Management, vol. 25, no. 7, pp. 603-622, 2005.

[62] L. Krajewski, J. C. Wei, and L.-L. Tang, "Responding to schedule changes in build-to-order supply chains," Journal of Operations Management, vol. 23, no. 5, pp. 452-469, 2005.

[63] G. A. Peñaloza, D. D. Viana, F. S. Bataglin, C. T. Formoso, and I. R. Bulhões, "Guidelines for integrated production control in engineer-to-order prefabricated concrete building systems: preliminary results," in Proceedings of the 24th Annual Conference of the International Group for Lean Construction, Boston, MA, USA, July 2016.

[64] L. S. Pheng and M. S. Hui, "The application of JIT philosophy to construction: a case study in site layout," Construction Management and Economics, vol. 17, no. 5, pp. 657-668, 1999.

[65] K. S. Im, S. H. Han, B. Koo, and D. Y. Jung, "Formulation of a pull production system for optimal inventory control of temporary rebar assembly plants," Canadian Journal of Civil Engineering, vol. 36, no. 9, pp. 1444-1458, 2009.

[66] S. P. Low and M. Wu, "Just-in-time management in the ready mixed concrete industries of Chongqing, China and Singapore," Construction Management and Economics, vol. 23, no. 8, pp. 815-829, 2005.

[67] Q. Chen, B. García de Soto, and B. T. Adey, "Supplier-contractor coordination approach to managing demand fluctuations of ready-mix concrete," Automation in Construction, vol. 121, Article ID 103423, 2021.

[68] M. Goh and Y. M. Goh, "Lean production theory-based simulation of modular construction processes," Automation in Construction, vol. 101, pp. 227-244, 2019.

[69] D. J. Bryde and R. Schulmeister, "Applying Lean principles to a building refurbishment project: experiences of key stakeholders," Construction Management and Economics, vol. 30, no. 9, pp. 777-794, 2012.

[70] National and AIA California Council, Integrated Project Delivery: A Guide, Vol. 2019, The American Institute of Architects, Washington, DC, USA, 2007.

[71] D. C. Kent and B. Becerik-Gerber, "Understanding construction industry experience and attitudes toward integrated project delivery," Journal of Construction Engineering and Management, vol. 136, no. 8, pp. 815-825, 2010.

[72] Q. Ju, L. Ding, and M. J. Skibniewski, “Optimization strategies to eliminate interface conflicts in complex supply chains of construction projects," Journal of Civil Engineering and Management, vol. 23, no. 6, pp. 712-726, 2017.

[73] P. Lahdenperä, "Making sense of the multi-party contractual arrangements of project partnering, project alliancing and integrated project delivery," Construction Management and Economics, vol. 30, no. 1, pp. 57-79, 2012.

[74] P. Nguyen and R. Akhavian, "Synergistic effect of integrated project delivery, lean construction, and building information modeling on project performance measures: a quantitative and qualitative analysis," Advances in Civil Engineering, vol. 2019, Article ID 1267048, 9 pages, 2019.

[75] F. Elghaish, S. Abrishami, M. R. Hosseini, and S. Abu-Samra, "Revolutionising cost structure for integrated project delivery: a BIM-based solution," Engineering, Construction and Architectural Management, vol. 28, pp. 1-27, 2020.

[76] J. Ma, Z. Ma, and J. Li, "An IPD-based incentive mechanism to eliminate change orders in construction projects in China," KSCE Journal of Civil Engineering, vol. 21, no. 7, pp. 25382550, 2017.

[77] J. F. Y. Yeung, A. P. C. Chan, and D. W. M. Chan, "Defining relational contracting from the Wittgenstein family- 
resemblance philosophy," International Journal of Project Management, vol. 30, no. 2, pp. 225-239, 2012.

[78] L. S. Pheng and C. J. Chuan, "Just-in-time management of precast concrete components," Journal of Construction Engineering and Management, vol. 127, no. 6, pp. 494-501, 2001.

[79] M. Khalfan, P. McDermott, A. Oyegoke et al., "Application of Kanban in the UK construction industry by public sector clients," in Proceedings of the 16th Annual Conference of the International Group for Lean Construction, pp. 347-359, University of Salford, Manchester, UK, July 2008.

[80] J. G. Jeong, M. Hastak, M. Syal, and T. Hong, "Internal relationship modeling and production planning optimization for the manufactured housing," Automation in Construction, vol. 20, no. 7, pp. 864-873, 2011.

[81] B. Anvari, P. Angeloudis, and W. Y. Ochieng, "A multi-objective GA-based optimisation for holistic manufacturing, transportation and assembly of precast construction," Automation in Construction, vol. 71, pp. 226-241, 2016.

[82] L. Kong, H. Li, H. Luo, L. Ding, X. Luo, and M. Skitmore, "Optimal single-machine batch scheduling for the manufacture, transportation and JIT assembly of precast construction with changeover costs within due dates," Automation in Construction, vol. 81, pp. 34-43, 2017.

[83] S. Salimi, M. Mawlana, and A. Hammad, "Performance analysis of simulation-based optimization of construction projects using high performance computing," Automation in Construction, vol. 87, pp. 158-172, 2018.

[84] Q. Chen, D. M. Hall, B. T. Adey, and C. T. Haas, "Identifying enablers for coordination across construction supply chain processes: a systematic literature review," Engineering, Construction and Architectural Management, vol. 28, no. 4, pp. 1083-1113, 2020.

[85] T. M. Simatupang and R. Sridharan, "An integrative framework for supply chain collaboration," The International Journal of Logistics Management, vol. 16, no. 2, pp. 257-274, 2005.

[86] Z. Wang and H. Hu, "Dynamic response to demand variability for precast production rescheduling with multiple lines," International Journal of Production Research, vol. 56, no. 16, pp. 5386-5401, 2018.

[87] J. Du, P. Dong, and X. Wang, "Multi-objective genetic algorithm based prefabricated component production process optimization considering the demand fluctuations in the construction site," in Proceedings of the International Conference on Applications and Techniques in Cyber Intelligence, ATCI 2018, M. Atiquzzaman, Z. Xu, J. Abawajy et al., Eds., vol. 842, pp. 469-476, Springer-Verlag, Heidelberg, Germany, September 2019.

[88] A. T. De Albuquerque, M. K. El Debs, and A. M. C. Melo, “A cost optimization-based design of precast concrete floors using genetic algorithms," Automation in Construction, vol. 22, pp. 348-356, 2012.

[89] C. Chen, D. Tran Huy, L. K. Tiong, I.-M. Chen, and Y. Cai, "Optimal facility layout planning for AGV-based modular prefabricated manufacturing system," Automation in Construction, vol. 98, pp. 310-321, 2019. 